\title{
FUSULINID SUCCESSION FROM THE MIDDLE-UPPER CARBONIFEROUS BOUNDARY BEDS ON SPITSBERGEN, ARCTIC NORWAY
}

\author{
Vladimir I. Davydov and Inger Nilsson
}

\begin{abstract}
New fusulinid data from the Kolosseum locality, central Spitsbergen, show the process of fusulinid evolution in transitional Middle to Upper Carboniferous beds of the Arctic region. This well-preserved fusulinid fauna provides a clear understanding of the nature of Moscovian-Kasimovian fusulinid evolution; particularly in the Arctic region. Fusulinid assemblages in the Moscovian/Kasimovian boundary beds in Spitsbergen show a predominance of representatives of the Protriticites-Montiparus-Rauserites lineage. Representatives of the Praeobsoletes-Obsoletes-Triticites lineage in Spitsbergen are very rare and occur later than in the stratotype region, the Russian Platform. Four fusulinid zones similar to zones in the stratotype area are defined upwards: Fusulinella bocki Zone, Protriticites ex. gr. ovatus-Quasifusulinoides quasifusulinoides Zone, Protriticites pseudomontiparus-Obsoletes obsoletus Zone and Montiparus montiparus Zone, respectively. Precise correlation of the Moscovian/Kasimovian transition of Spitsbergen to adjacent areas (Northeast Greenland and Canadian Arctic) as well as with the Moscovian-Kasimovian of the region of the Moscow basin, Spain, and Carnic Alps is suggested. The Moscovian/Kasimovian boundary of Eurasia is approximately correlative with the Middle Desmoinesian (base of DS-3 fusulinid zone of Wilde 1990) of North America. Data from Spitsbergen are of great importance for resolving the problem of Middle/Upper Carboniferous boundary recognition regarding fusulinid phylogenies.

Davydov, Vladimir I., All Russian Geological Research Institute (VSEGEI), St. Petersburg and Permian Research Institute (PRI), Boise State University, Department of Geosciences, 1910 University Drive, Boise, ID, 83725, USA

Nilsson, Inger, Saga Petroleum ASA, P.O. Box 490, N-1301, Sandvika, Norway

Keywords: fusulinids, evolution, Moscovian, Kasimovian, Arctic

Copyright: Paleontological Society

Submission: 5 June 1998, Acceptance: 31 December 1998

http://www-odp.tamu.edu/paleo/1999 1/fusulinid/issue1 99.htm
\end{abstract}

\section{INTRODUCTION}


Fusulinids are widely distributed in Middle Carboniferous to Lower Permian shallow marine deposits of Spitsbergen, the main island of Svalbard Archipelago (Fig. 1). Upper Paleozoic strata exist throughout the archipelago, but the largest outcrops occur in the central Spitsbergen region. In this area the Carboniferous-

Permian succession is relatively unaffected by post-Paleozoic tectonic activity. Middle- and Upper Carboniferous fusulinid zones in deposits from Spitsbergen have been reported previously by Forbes (1960), Cutbill and Challinor (1965), Sossipatrova (1967), Nilsson (1988, 1993), Nilsson and Davydov (1992, 1997) and Igo and Okamura (1992). New data presented here focus on the fusulinid fauna from the uppermost Moscovian and lower to middle Kasimovian beds at the Kolosseum locality (Fig. 1). Data from this section are of special interest because a relatively thick

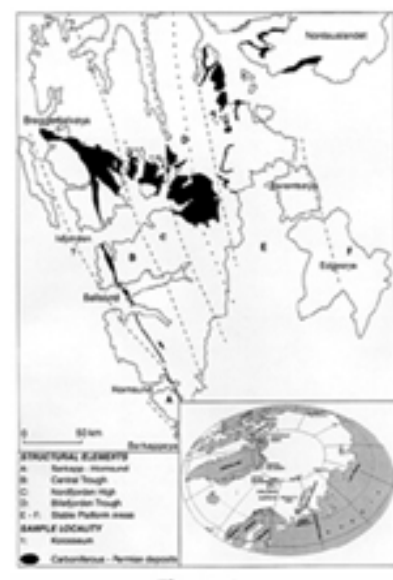

Figure 1. unit represents the Moscovian-Kasimovian boundary beds, and well-preserved fusulinids are recorded from many levels within the section. The frequent occurrence and unique preservation of fusulinids in these strata offers an opportunity to study the process of the fusulinid evolution in transitional Middle to Upper Carboniferous beds based on their ontogeny.

The problem of Moscovian/Kasimovian boundary recognition has been considered for several years by the Moscovian/Kasimovian Working Group (formerly WG 5) of the Subcommission on Carboniferous Stratigraphy (SCCS) (Villa et al. 1994). The efforts of the WG members from different areas have concentrated on working out detailed biozonation in the boundary beds and tracing this zonation as widely as possible. The fusulinid faunas of Spitsbergen have important paleobiogeographic implications as they act as faunal links between the diverse faunas known from Russia (e.g., Russian Platform, Timan-Pechora Basin and Urals) in the east and Northeast Greenland (Wandel Sea Basin) and the Canadian Arctic (Sverdrup Basin) in the west. These basins were included in the Franklinian Shelf in fusulinacean paleobiogeographic reconstruction of Ross (1995). New fusulinid data from Spitsbergen are regarded as being of great importance for resolving the problem of the Middle/Upper Carboniferous boundary recognition.

\section{LITHOSTRATIGRAPHY AND MATERIAL}


The present Middle-Upper Carboniferous and Lower Permian lithostratigraphy for central Spitsbergen is based on Cutbill and Challinor (1965) and Dallmann et al. (in press) (Figure 2). This succession is assigned to the Gipsdalen Group and is dominated by carbonate and evaporite sequences with minor clastic input.

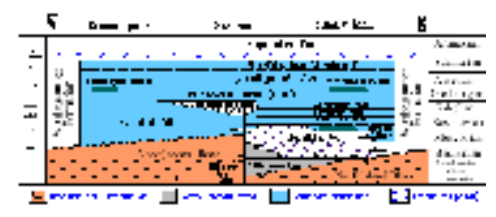

Flgure 2.

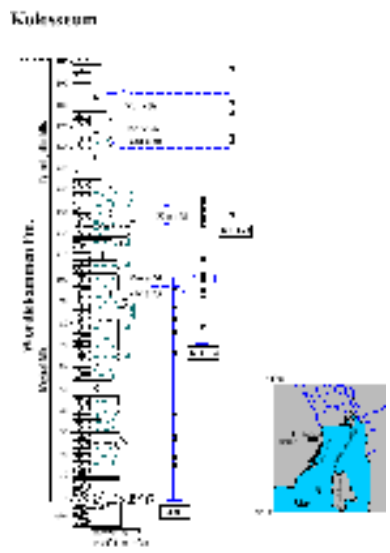

FIgure 3 .

In the investigated area of central

Spitsbergen, the Gipsdalen Group is represented by the Wordiekammen and Gipshuken Formations. This study is based on fusulinid samples from the Kapitol Member of the Wordiekammen Formation.

The Kolosseum section is located in the western part of the Nordfjorden High, central Spitsbergen (Figure 1). At this locality the Middle-Upper Carboniferous Kapitol Member rests unconformably on Devonian strata. Fusulinid-bearing rocks of the Kolosseum section were sampled every 1-3 $\mathrm{m}$ in the Moscovian/Kasimovian boundary beds, and every 5-10 m elsewhere (Figure 3).

More than 150 thin-sections with oriented fusulinids were prepared for this study. Seventy-two species of 14 genera of fusulinids were identified (Figure 4).

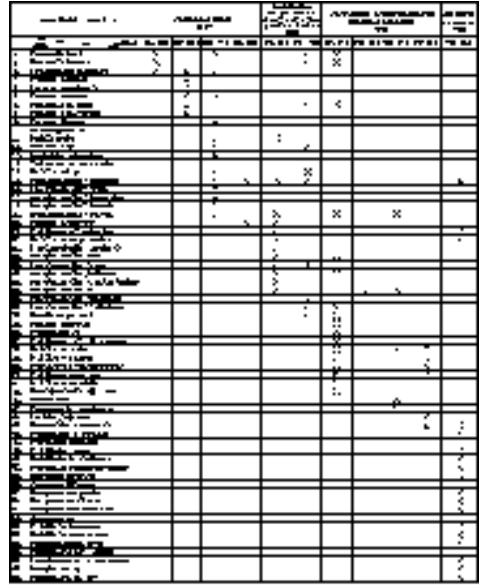

FIgure 4 . 


\section{FUSULINID ZONES IN THE KOLOSSEUM SECTION}

\section{Fusulinella bocki Zone (Figure 5)}

The body of strata between the first appearance of Fusiella typica, Fusulinella bocki, Pseudofusulinella pulchra, Quasifusulinoides? kolensis and first appearance of the representatives of the Protriticites and typical Quasifusulinoides.

Reference section. Between $28.0 \mathrm{~m}$ and $76.0 \mathrm{~m}$ in the Kolosseum section, central Spitsbergen (Figures 3-4).

Composition. Fusiella typica Lee and Chen, Neostaffella sphaeroidea (Ehrenberg em. Moeller), Plectofusulina sp., Fusulinella bocki Moeller, F. helenae Rauser, F. mosquensis Rauser, Protriticites? sp., Pseudofusulinella pulchra (Rauser and Belyaev),

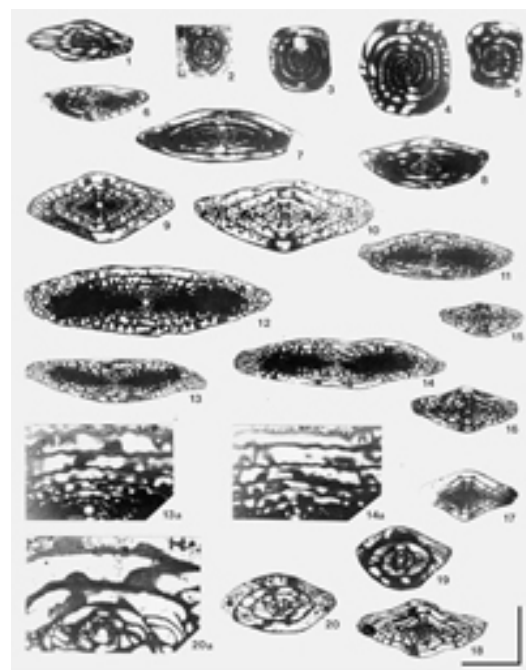

Figure 5 . Beedeina elshanica (Putrja and Leontovich), B. paradistenta (Safonova), B. samarica (Rauser and Belyaev), Quasifusulinoides? kolensis Nilsson, Quasifusulinoides? intermedius (Rauser and Gryzlova), Quasifusulinoides? firmus (Rauser), Wedekindellina dutkevichi Rauser and Belyaev, W. subovata Safonova, W. uralica (Dutkevich) (Figure 4).

Chronostratigraphical age. Late Moscovian, early Myachkovian (Novlinskian).

Comments. The recorded assemblage comprises fauna of a mixed nature, where typical Moscovian genera like Wedekindellina, Beedeina, and Fusulinella occur together with the first Quasifusulinoides? Most of the recorded fauna is typically Myachkovian and is dominated by numerous Wedekindellina, Fusulina, Beedeina, Fusulinella, Pseudofusulinella pulchra, and rare Neostaffella. In the middle part of the zone $(38.0 \mathrm{~m})$ transitional forms (Protriticites?) between typical Fusulinella and Protriticites first occur. These specimens are characterized by thicker walls in the outermost volution and straighter pores in the inner tectorium than are observed in Fusulinella (Figure 5.20A). These features are variable, however, and these specimens are still assigned to the genus Fusulinella.

Elongate Quasifusulinoides? with massive secondary deposits but thin walls, occur in an assemblage of this zone. In the wall of elongate Quasifusulinoides? the diaphanotheca becomes more grey and less distinct. The diaphanotheca appears to merge with the inner tectorium, though some specimens posses a well-defined fourlayered wall with diaphanotheca in the inner volutions (Figures 5.13A, 5.14A). These specimens are transitional forms between typical Fusulina and Quasifusulinoides. Quasifusulinoides? with transitional features constitute only a small part of the assemblage however. In the stratotype area of the Moscow Basin typical 
Quasifusulinoides are first found in upper Myachkovian deposits, i.e. those younger than Fusulinella bocki fusulinid Zone (Rauser-Chernousova et al. 1951; RauserChernousova and Reitlinger 1954; Davydov 1997a).

\section{FUSULINID ZONES IN THE KOLOSSEUM SECTION (continued)}

\section{Protriticites ex gr. ovatus-Quasifusulinoides quasifusulinoides Zone (Figure 6)}

Definition of biozonal limits. The body of strata between the first appearance of primitive Protriticites (Protriticites ex gr. ovatus) and typical Quasifusulinoides ( $Q$. quasifusulinoides group) and the first appearance of advanced Protriticites (Pr. pseudomontiparus group).

Reference section. Between 76.0 and $81.0 \mathrm{~m}$ in the Kolosseum section, central Spitsbergen (Figure 4).

Chronostratigraphical age. Latest Moscovian, late Myachkovian (Peskovskian).

Composition. This zone is defined by the occurrence of Protriticites ex gr. ovatus Putrja and Quasifusulinoides quasifusulinoides (Rauser). Other species included in this zone are: Fusiella praelancetiformis Safonova, F. typica Lee and Chen, F. praecursor Rauser, Plectofusulina sp., Oketaella? sp., Wedekindellina sp., Quasifusulinoides aff. fusulinoides (Putrja), Q. firmus (Rauser), Q. intermedius (Rauser), Q. fusiformis (Rosovskaya), Q. blear (Rauser), Q. shapkiensis (Konovalova), Quasifusulinoides? fortissimus (Rauser), Fusulinella bocki Moeller, F. helenae Rauser, F. timanica Rauser, Protriticites aff. ovatus, P. aff. sphaericus Volozhanina (transitional form between Fusulinella sp. and P. sphaericus), P. aff. inflatus Bensh, Pseudofusulinella eopulchra (Rauser), Pseudofusulinella? pulchra (Rauser and Belyaev), and P. ylychensis (Rauser) (Figure 4).

Comments. The assemblage of this zone is transitional between typical Upper Moscovian and Lower Kasimovian fusulinid faunas. Typical Moscovian genera such as Wedekindellina, Neostaffella, Fusulina, Beedeina, and Fusulinella occur very rarely. At the base of this zone Quasifusulinoides and Protriticites first begin to predominate. However, the wall of Protriticites is still not quite typical. The diaphanotheca is well-defined, but pores in the inner tectorium are not quite distinct (Figures 6.15A, 6.16A). Quasifusulinoides is represented by typical specimens characterized by a thin, three-layered wall consisting of tectum, outer tectorium and an 
inner layer which is homologous to an 5 inner tectorium. This inner layer shows a gradual merging of diaphanotheca and inner tectorium, providing an indistinct boundary between these layers (Figure 6.5A). Fusiella in this bed are more developed than in the previous assemblage, being of larger size, having a larger number of volutions, and a more elongate shell. In the Moscow Basin these species of Protriticites, Quasifusulinoides, and Fusiella occur in the Peskovskaya Formation of Upper Myachkovian age.

At $79.0 \mathrm{~m}$ the fusulinid fauna is almost the same. Fusulinella, Pseudofusulinella, Quasifusulinoides, Protriticites and transitional forms between Fusulinella and Protriticites occur. Quasifusulinoides in this bed have well-defined pores in the inner tectorium, but the diaphanotheca is still discernable. Pores in the diaphanotheca are only weakly developed. In the Fusulinella-Protriticites lineage there occur forms with a thickened inner tectorium traversed with coarser pores and a distinct diaphanotheca.

The peculiarity of this assemblage is the domination of Quasifusulinoides and Protriticites, and the absence of Praeobsoletes, which dominates at the same level in the stratotype area. The assemblage shows close affinities to fusulinid fauna from the Peskovskaya Formation of the stratotype area, which form the upper part of the Myachkovian Horizon in the Moscow Basin (Rauser-Chernousova et al. 1951; RauserChernousova and Reitlinger 1954; Makhlina et al. 1984; Davydov 1997a). The Protriticites ex. gr. ovatus-Quasifusulinoides quasifusulinoides Zone is therefore regarded as being of latest Moscovian (late Myachkovian, Peskovskian) age. 


\title{
FUSULINID ZONES IN THE KOLOSSEUM SECTION (continued)
}

\author{
Protriticites pseudomontiparus, Obsoletes obsoletus \\ Zone (Figures 7, $\underline{8}$ )
}

Definition of biozonal limits: The body of strata between first appearance of Protriticites pseudomontiparus, advanced Protriticites, and Praeobsoletes burkemensis, and the first appearance of Montiparus.

Reference section. Between 81.0 and $95.5 \mathrm{~m}$ in the Kolosseum section, central Spitsbergen (Figure 4).

Chronostratigraphical age. Early Kasimovian, Krevyakinian.

Composition. Fusiella rawi Lee, F. lancetiformis Putrja, Fusulinella bocki Moeller, F. aff. bocki Moeller, F.

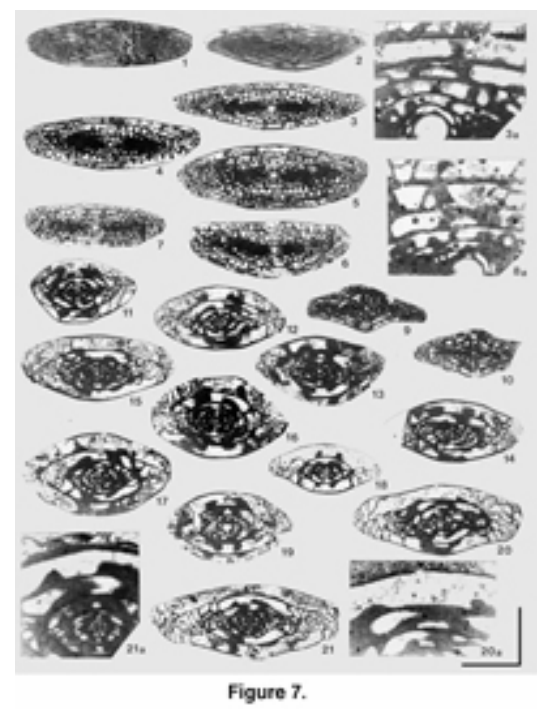
helenae Rauser, Fusulina pachrensis Rauser, Protriticites pseudomontiparus Putrja, P. ovatus Putrja, P. variabilis Bensh, P. cf. variabilis Bensh, P. ovoides Putrja, P. ovatus Putrja, P. plicatus Kireeva, P. plicatissimus Kireeva, P. sphaericus Volozhanina, P. cf. sphaericus Volozhanina, P. subovatus Bensh, $\mathbf{P}$. aff. subovatus Bensh, $\mathbf{P}$. subschwagerinoides Rosovskaya, transitional form between Protriticites and Montiparus, Praeobsoletes sp., Praeobsoletes burkemensis (Volozhanina), Obsoletes fusiformis Bensh, Quasifusulinoides blear (Rauser), Q. fusiformis (Rosovskaya), Q. fortissimus (Rauser), Q. quasifusulinoides (Rauser), Pseudofusulinella usvae (Dutkevich), Pseudofusulinella? pulchra (Rauser and Belyaev), (Figure 4).

Comments. Fusulinella and Fusulina occur as single specimens in the lowermost part of this zone while Protriticites is abundant. The latter is characterized by a thick wall, thickening of the inner tectorium and more conspicuous almost branching pores. The diaphanotheca is grey and some times even absent (Figure 7.21A). The wall of Quasifusulinoides has well-defined pores in the inner tectorium (Figures 7.3A, 7.8). The wall of Praeobsoletes is very thin with only two layers in the outer 1 to 1.5 volutions; it consists of a tectum and gray structureless primatheca (Figure 7.20A).

The fusulinid fauna at $87.5 \mathrm{~m}$ resembles the fauna at $81.0 \mathrm{~m}$. The outermost volution of many of the recorded Protriticites shells is crushed, however, and the characteristics of the genus are therefore not well distinguished. Nevertheless, there occur a number of specimens with well-defined, thick walls that have a thick inner tectorium with distinct coarse pores. Within this level, very subcylindrical Fusiella rawi Lee occur, and this species is common in Kasimovian strata (Villa et al. 1993; Davydov 1997a, 1997b). Praeobsoletes and rare Fusulinella, Pseudofusulinella, and Fusulina are also 
present at $87.5 \mathrm{~m}$.

At $91.5 \mathrm{~m}$ Protriticites is represented by species with coarse pores in an inner tectorium that transforms locally into a keriotheca. In the outermost volution of some specimens, trabeculars similar to those of Montiparus are observed in the inner tectorium (Figures 8.9A, 8.12A). These forms have a gray diaphanotheca that nearly merges with the inner tectorium. One specimen with more massive chomata and more intensive septal fluting was found (Figure 8.13). Apparently, this form represents the most developed Protriticites, that occupies an intermediate position between Protriticites and Montiparus.

Earliest Obsoletes exhibit a thin two-layered wall with portions of trabeculars in the last volution (Figure 8.3A). Compared with the corresponding assemblage of the stratotype area, Praeobsoletes and Obsoletes seem to occur later in Spitsbergen. The same pattern is observed in Moscovian/Kasimovian beds of the Cantabrian Mountains of Spain (Villa et al. 1993) and in Carnic Alps (Krainer and Davydov, 1998).

Rare Pseudofusulinella usvae are present in this assemblage. Studied specimens of this species appear to be more advanced than in underlying beds as they are larger in size, slightly more elongate, and exhibit tighter coiling.

Based on fusulinid composition of the assemblage and the fusulinid distribution in the section, the zone under discussion fully corresponds to the Protriticites pseudomontiparus-Obsoletes obsoletus Zone of the Krevyakinian Horizon of the Moscow region (Davydov 1997a). Similar assemblages are also reported from the Lower Kasimovian of the Urals, Timan-Pechora Basin, Donets Basin, Central Asia, Northern Timan, Cantabrian Mountains and Carnic Alps (Scherbakov et al. 1984; Kireeva 1950, Davydov 1984, 1990a, 1990b, 1992, 1997a, 1997b; Konovalova 1991; Remizova 1997; Bensh 1972; Villa et al. 1994; Davydov and Krainer, in press). 


\section{FUSULINID ZONES IN THE KOLOSSEUM SECTION (continued)}

\section{Montiparus montiparus Zone (Figure 9)}

Definition of biozonal limits. The base of this zone is defined by the first appearance of Montiparus. The top of the zone is not defined due to lack of productive samples in this part of the section (Nilsson 1993).

Reference section. At $95.5 \mathrm{~m}$ in the Kolosseum section, central Spitsbergen (Figure 4).

Chronostratigraphical age. Middle Kasimovian, Khamovnichenian.

Composition. Montiparus montiparus (Ehrenberg em. Moeller), Montiparus ex. gr. montiparus (Ehrenberg em. Moeller), Montiparus calitvicus (Putrja), Montiparus

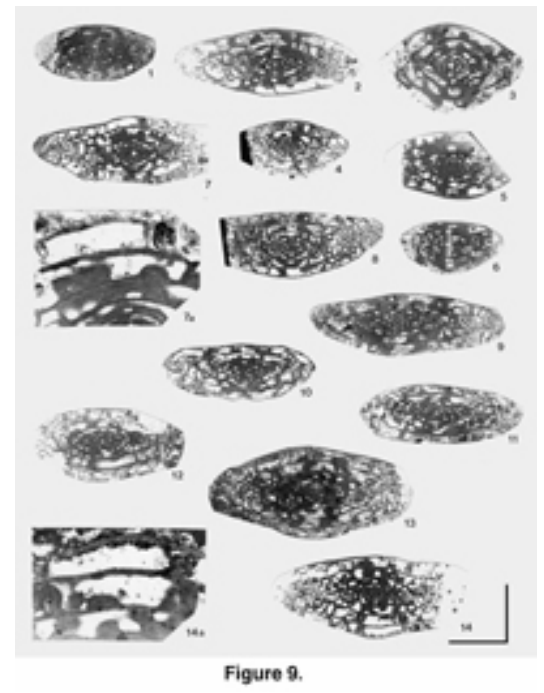
likharevi (Putrja), Montiparus mesopachus Rosovskaya, M. umbonoplicatus (Rauser and Belyaev), Montiparus aff. umbonoplicatus (Rauser and Belyaev), Montiparus ex. gr. umbonoplicatus (Rauser and Belyaev), Montiparus? spp., Protriticites sphaericus Volozhanina, Protriticites ovoides Putrja, P. lamellosus Kireeva, P. manukalovae Kireeva., P. cf. ovatus Putrja, Protriticites? sp., Quasifusulina aff. eleganta Shlykova, Q. ex. gr. Iongissima (Moeller) sp. nov., Pseudofusulinella usvae (Dutkevich) and Nodosaria sp.

Comments. In this zone Quasifusulinoides is replaced by typical Quasifusulina that possess a very thin two-layered wall. Montiparus is abundant and exhibit three-layered keriothecal wall consisting of tectum, keriotheca and outer tectorium (Figures 9.7A, 9.14A). Septal fluting of Montiparus is more intensive, and chomata are massive. These Montiparus are represented by relatively primitive forms characteristic of the Ratmirovskaya Fm. --the lower Formation of Khamovnichenian Horizon in the Moscow Basin.

However, Protriticites and Pseudofusulinella usvae are very rare in this zone. Nodosaria sp. are found in this zone, and seem to be one of the earliest representative of this genus. The Obsoletes-Triticites lineage appears to be absent at the Kolloseum section.

The recorded fauna from the Montiparus montiparus Zone of Spitsbergen compares well with that of the lower portion of the Khamovnichenian Horizon of the Kasimovian of the Moscow Basin and to Montiparus paramontiparus zone of the Donets Basin, North Timan, Spain and Carnic Alps (Rauser-Chernousova and Scherbovich 1974; Davydov 1990a, 1990b, 1992, 1997a, 1997b; Remizova 1997; Villa et al. 1994; Krainer 
and Davydov, 1998).

\section{DISCUSSION AND CORRELATION}

The Middle/Upper Carboniferous boundary in the stratotype area of the Moscow Basin is placed at the base of the Krevyakinian Horizon (Ivanov 1926, Dan'shin 1947) (Figure 10). This boundary was traditionally defined by fusulinids in the 1950's (RauserChernousova et al. 1951; RauserChernousova and Reitlinger 1954; RauserChernousova and Scherbovich 1974; Ivanova and Khvorova 1955), and the base of the

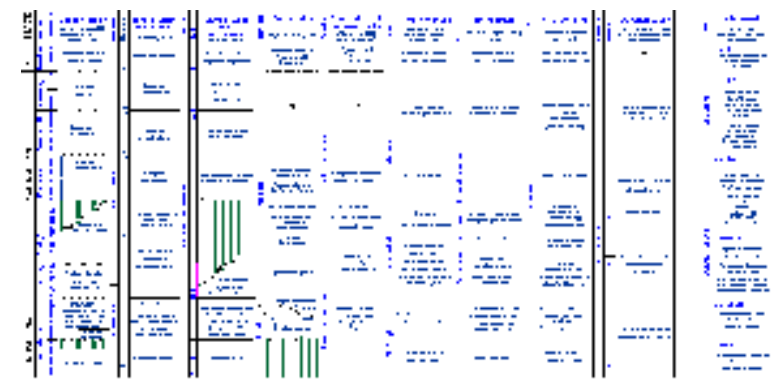

Flgure 10. Protriticites pseudomontiparus-Obsoletes obsoletus Zone was assigned to correspond to the base of the Kasimovian (i.e. base of Krevyakinian Horizon). This definition is accepted and widely used.

\section{Former Soviet Union}

In the Russian Platform, Timan-Pechora Basin, Urals, Donets Basin and Central Asia the Middle/Upper Carboniferous boundary is defined by the first occurrence of Obsoletes and accompanying advanced Protriticites and Quasifusulinoides (Rauser-Chernousova and Scherbovich 1974; Davydov 1986, 1990a, 1990b, 1997a, 1997b; Konovalova 1991; Remizova 1995). However, representatives of the latter two genera first appear in the underlying upper Myachkovian beds (i.e. uppermost Moscovian). Protriticites, Quasifusulinoides, and Obsoletes can be identified only if their tests are well preserved. Even slight recrytallization hampers recognition of these genera. Some specialists deny the independence of these genera for this reason (Villa et al. 1993). Distinct changes in fusulinid wall structure (i.e., well-defined trabecularity of keriotheca) are observed at the base of the Montiparus montiparus Zone, and some investigators prefer therefore to place the Moscovian/Kasimovian boundary at the base of this zone (i.e., at the base of the Khamovnichenian Horizon in the stratotype section of the Moscow Basin area; Remizova 1997; Villa et al. 1993).

The problem of the Moscovian/Kasimovian boundary has recently been discussed by Davydov (1997a). Several variations of the Moscovian/Kasimovian boundary position were considered:

1. At the base of Praeobsoletes burkemensis-Protriticites ovatus Zone corresponding to the base of the Protriticites Genozone and Peskovskyi Fm. of 
Myachkovian Horizon in the Moscow Basin.

2. At the base of Protriticites pseudomontiparus-Obsoletes obsoletus Zone that places the classical Moscovian/ Kasimovian boundary at the base of Krevyakinskian Horizon.

3. At the base of the Montiparus montiparus Zone corresponding to the base of Khamonicheskian Horizon.

Based on the latest fusulinid and conodont studies in the region of the Moscow Basin (Alekeseev et al. 1994; Davydov 1997a) the best correlation potential is shown by the following boundaries:

A) at the base of the Suvurovskaya Fm. (or probably base of "liska" bed of the Peskovskaya Fm. of the Myachkovian Horizon) - the base of the Protriticites pseudomontiparus, Obsoletes obsoletus Zone and its equivalent the Streptognathodus subexcelsus conodont Zone;

B) at the base of the Montiparus paramontiparus Zone and its equivalent the Streptognathodus oppletus conodont Zone (Villa et al. 1997; Davydov 1997a).

Based on evidence mentioned above, we can conclude that the Moscovian/Kasimovian boundary problem still is unresolved in the stratotype area and the boundary therefore should be left at an accepted level, i.e. at the base of the Krevyakinian Horizon, that corresponds to the base of the Protriticites pseudomontiparus-Obsoletes obsoletus Zone and base of Streptognathodus subexcellsus conodont Zone.

\section{Spain}

In the Cantabrian Mountains lower Myachkovian assemblage with Fusulinella bocki occur in the middle portions of Picos de Europa Formation (Villa et al. 1997). In the upper portion of this formation, primitive Protriticites first appear together with conodonts resembling Streptognathodus subexcellsus. The base of the Kasimovian is established based on the occurrence of Protriticites pseudomontiparus and other advanced Protriticites, and by the first appearance of Praeobsoletes. First Obsoletes occur together with Montiparus (i.e., higher in the section than in the stratotype area). The same phenomena is observed in the Kolosseum section at Spitsbergen, where Praeobsoletes and Obsoletes appear slightly later than in the stratotype area.

\section{Carnic Alps}

The lower most portion of the Upper Paleozoic succession in the Carnic Alps has been restudied recently (Krainer and Davydov 1998). The Bombaso Formation and basal Meledis Formation in the central Carnic Alps near Straniger Alm and Zollnersee (Austria/ltaly border) consist of shallow marine clastic and carbonate sediments that are arranged to form two fining and deepening upward sequences. Limestones in particular and even breccias of the Bombaso and lower Meledis Formation yield a rich fusulinid 
fauna composed of 33 species that are attributed to the following zones:

Quasifusulinoides quasifusulinoides-Protriticites ovatus; Protriticites pseudomontiparus, and Montiparus montiparus. Breccia of the Bombaso Formation west of Straniger Alm contains the oldest fusulinid fauna of the Carnic Alps, belonging to the Quasifusulinoides quasifusulinoides - Protriticites ovatus Zone corresponding to the Peskovskaya Formation of the Myachkovian Horizon in the Moscow basin indicating uppermost Moscovian age. A similar assemblage is found in limestones from depositional sequence 1 at Zollnersee (Krainer and Davydov 1998). Limestones and calcareous sandstones-siltstones of the basal Meledis Formation of depositional sequence 2 near Zollnersee and at Cima Val di Puartis are characterized by fusulinids of the Protriticites pseudomontiparus Zone (Protriticites globulus, Pr. pseudomontiparus, Pr. sphaericus, Pr. rotundatus, Pr. ovoides, Pr. lamellosus, and Praeobsoletes burkemensis) and by Montiparus paramontiparus Zone (Praeobsoletes pauper, P. burkemensis, Obsoletes timanicus, O. obsoletus, Montiparus paramontiparus, $M$. umbonoplicatus, M. montiparus, M. likharevi, $M$. rhombiformis, and M. priscus) indicating correlation to Krevyakinian (Lower Kasimovian) and Khamovnichenian Horizons (Middle Kasimovian) of the Russian Platform, respectively. In the Carnic Alps, Praeobsoletes and Obsoletes first occur in the Khamovnichenian Horizon (i.e., later than in the stratotype area).

\section{Northeast Greenland (Wandel Sea Basin)}

New fusulinid collections from Amdrup Land have recently been studied by Davydov and Nilsson. Beds with Beedeina paradistenta, Fusulinella praebocki, Pseudofusulinella eopulchra and primitive Protriticites are correlated with the Peskovskaya Formation of the upper Myachkovian Horizon in the Moscow Basin. These beds are overlain by beds with advanced Protriticites, Quasifusulinoides, rare Praeobsoletes, Obsoletes, and Plectofusulina. This assemblage corresponds to the Krevyakinian Horizon of the Lower Kasimovian in the Moscow Basin. Higher in the section Quasifusulina, Montiparus, and rare Protriticites occur. This assemblage is correlative with the Khamovnichenian Horizon (Middle Kasimovian) in the Moscow Basin. Beds with assemblages of Quasifusulina, Montiparus, and rare Protriticites are overlain by beds with numerous Quasifusulina and the first Rauserites, that correlate with the Dorogomilovian Horizon (Upper Kasimovian) in the Moscow Basin. Moscovian-Kasimovian fusulinid assemblages in Northeast Greenland show strong similarities with those in Spitsbergen and correlate well with the Moscovian-Kasimovian transition in the stratotype sections of the Moscow Basin.

\section{Canadian Arctic}

In the Canadian Arctic (Sverdrup Basin) fusulinids from the Middle/Upper Carboniferous boundary beds are reported by Rui Lin et al. (1991), Nilsson (1993) and Rui Lin and Nassichuck (1994). An upper Moscovian Fusulinella eopulchra assemblage, a lower to middle Kasimovian Protriticites-Pseudofusulinella ex. gr. usvae assemblage and an upper Kasimovian Rauserites aff. quasiarcticus assemblage are recorded from the Canyon Fiord Formation (Nilsson 1993). Rui Lin et al. (1991) defined two upper 
Moscovian fusulinid zones in the type section of the Nansen Formation:

Wedekindellina lata-W. uralica longa Zone (units F-G) and "Fusulinella" eopulchra Zone (units H-L). The former zone is correlated by Rui Lin et al. (1991) with the Podolskian Horizon and the latter zone with the Myachkovian Horizon. We kindly were permitted by Dr. Nassichuk and Dr. Rui Lin to study the thin sections from the type section of the Nansen Formation. This study enabled us to propose another correlation of this section. We consider fusulinid assemblages from the units F-G most similar to the Myachkovian of the Moscow Basin. In particular, units F-G comprise species of Wedekindellina, Neostaffella, and Fusulinella, that are characteristic for the Myachkovian of the Moscow Basin (Rauser-Chernousova and Reitlinger 1954). The fusulinid taxa notably change in the units $\mathrm{H}$-L. Typical Moscovian genera such as Wedekindellina and Neostaffella completely disappear while Fusulinella and Pseudofusulinella predominate. In unit $L$ we recognized Nodosaria aff. Iongissima Suleimanov and Raphconilia sp. Until now these small foraminifera were not known in deposits older than Kasimovian (Davydov 1988; Brenckle and Whalman 1993; Groves and Whalman 1997). Also in Spitsbergen Nodosaria has not been reported in beds older than Krevyakinian (Nilsson and Davydov 1992). "Fusulinella" eopulchra Zone of Rui Lin et al. (1991) is therefore partly of early Kasimovian and may be middle Kasimovian in age.

Rui Lin and Nassichuk (1994) describe two new fusulinid assemblages above unit $L$ in the type section of the Nansen Formation. Both "Protriticites" sp. A Zone (thickness $1.5 \mathrm{~m}$ ) and Eowaeringella placitasensis Zone (thickness $23 \mathrm{~m}$ ) are correlative with the Lower Missourian of the American Stratigraphic Scale and with the Krevyakinian Horizon of the Lower Kasimovian of the Moscow Basin . In our opinion however, their "Protriticites" fauna should belong to the genus Rauserites, because those specimens have a true keriothecal wall structure; sometimes slightly recrystallized. Rauserites occurs only from the beginning of the upper Kasimovian in the Moscow Basin, Urals, Donets Basin, Central Asia, North Greenland and Spitsbergen (Villa et al. 1994). Rauserites assemblage from type Nansen seems to correlate well to the Rauserites quasiarcticus Zone of the stratotype area (i.e., Dorogomilovian Horizon of Moscow Basin). Consequently, the proposed Moscovian/Kasimovian boundary in type Nansen by Rui Lin and Nassichuk (1994) is actually closer to the middle Kasimovian/upper Kasimovian boundary. In our opinion the Moscovian/Kasimovian boundary in the type Nansen should be placed at the base of unit $\mathrm{H}$.

\section{North America}

Correlation of fusulinids from Russia and Spitsbergen with North America can be performed only conventionally. Traditionally the Moscovian/Kasimovian boundary is correlative with the Desmoinesian/Missourian boundary, with Missourian being the approximate equivalent of the Kasimovian (Ross and Ross 1987). 
Rosovskaya (in Ivanova and Rosovskaya 1967) noted, however, that fusulinids from the base of Missourian, according to their evolutionary level, correspond to Upper Kasimovian fusulinids. Rosovskaya assumed a gap between the Desmoinesian and Missourian corresponding to the Krevyakinian and Khamovnicheian Horizons (Ivanova and Rosovskaya 1967). Accepting Rosovskaya's idea of the correspondence of the Lower Missourian and Upper Kasimovian, we propose a correlation between the

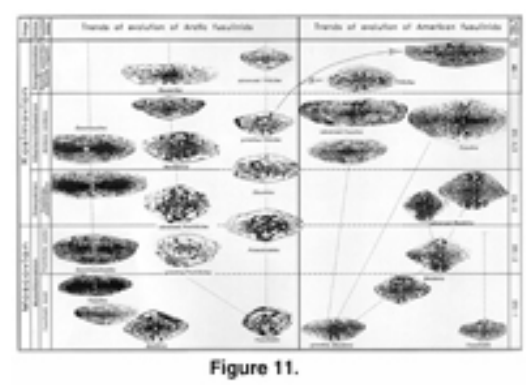
Desmoinesian with the Lower and Middle Kasimovian and the Lower Missourian with the Upper Kasimovian (Figure 11).

In Eurasia Fusulinella predominates at the end of the Myachkovian. It is simultaneously displaced by Protriticites and Praeobsoletes, that later are gradually followed by Montiparus and Rauserites in the first line (Figure 11), and by Obsoletes and Triticites in the second one respectively (Davydov 1990b). It is also at the end of the Myachkovian that Fusulina is displaced by Quasifusulinoides, that is followed by Quasifusulina in the Khamovnicheian (Chen-Tzin-Shi 1963). Beedeina disappears completely at the end of the Myachkovian.

The following fusulinid succession in the Upper Moscovian-Kasimovian in Eurasia is shown in Table 1.

In North America Fusulinella is scarce in the upper part of the Desmoinesian and disappears relatively quickly. Beedeina and Fusulina predominate during most of Desmoinesian. The evolution these genera in North America is very different from their evolution in Eurasia. Specialization and gigantism characterize evolution of Beedeina in North America. At the beginning of the Missourian in North America, Triticites abruptly occurs, perhaps as a result of migration. Triticites instantaneously displaces superspecialized Fusulina and Beedeina. Recently Wahlman et al. (1997) discovered Protriticites and probably Praeobsoletes fauna co-occur with Bartramella bartrami in the middle Desmoinesian. Table 2 shows recorded fusulinid zones of Desmoinesian (DS) and Missourian (MS) in USA by Wilde (1990).

Comparison of the Myachkovian-Kasimovian fusulinid succession of Eurasia with the Desmoinesian-Missourian fusulinid succession shows the following. Fusulinids from DS$1 \mathrm{a}, \mathrm{b}$ and DS-2a zones of the Desmoinesian are, according to their evolutionary level, correlative with those from the Myachkovian in the Russian Platform and to Fusulinella bocki and Protriticites ex. gr. ovatus-Quasifusulinoides quasifusulinoides zones in Spitsbergen. Fusulinids in succeeding Desmoinesian fusulinid zones (DS-2b, DS-3, DS4, and DS-5) differ essentially in a more advanced shell structure.

The first Missourian Eowaeringella and Triticites Fusulinid Zone replace Desmoinesian successions of Beedeina and Fusulina in the USA. According to their development these Triticites correspond to Triticites and Rauserites from the Upper Kasimovian (Dorogomilovian) of the Moscow Basin (Ivanova and Rosovskaya 1967). 
Position of DS-4, DS-5, DS-6 and DS-7 enables us to assume that the major part of the Desmoinesian corresponds to the Krevyakinian and Khamovnichenian Horizons of the Russian Platform. Desmoinesian Fusulinid Zones DS-4, DS-5, DS-6, DS-7 correspond to Protriticites pseudomontiparus and Montiparus montiparus fusulinid zones in Spitsbergen respectively. In summary, we propose that the Moscovian/Kasimovian boundary is correlative with the base of DS-3 (Middle-Upper zone of Beedeina and upper zone of Wedekindellina) by Wilde (1990) (Table 3).

Similar conclusions can be drawn based on ammonoids. Ammonoids in the Moscovian/ Kasimovian transition are, however, insufficiently studied because of their scarcity. Rare Moscovian ammonoids occur in the region of the Moscow Basin, Donets Basin and PaiKhoi (Ruzhenzev 1974). The earliest assemblage of Upper Carboniferous ammonoids (Dunbarites and Prouddenites) occurs in the lower part of the Kasimovian in Cape Chaika of the Pai-Khoi (Ruzhenzev 1974), where early Kasimovian fusulinids occur (Villa et al. 1994). This ammonoid assemblage is correlative with the Wewoka Formation of the middle Desmoinesian. According to Boardman et al. (1990), Dunbarites, Prouddenites, and Wewokites occur within the Marmaton Group, and these genera also correspond to the Desmoinesian. This enables correlation of the middle and upper portion of Marmaton Group with the Lower and Middle Kasimovian of the Russian Platform.

The proposed correlation is also supplemented by conodont data. Conodonts in the Moscovian and the Kasimovian are also inadequately studied, especially in North America. Streptognathodus exelsus and St. oppletus, that occur in the Krevyakinian in the Moscow Basin (Alekseev et al. 1994; Villa et al. 1997), are also known in the Desmoinesian of North America (Merrill 1975). Idiognathodus saggitalis Kosenko, that is characteristic of the upper part of the Khamovnicheian and Dorogomilovian in the Moscow Basin (Alekseev et al. 1994), occurs at the base of the Missourian in North America (Barrick et al. 1996). These observations also suggest an approximate correspondence of Upper Desmoinesian and Lower-Middle Kasimovian strata.

To compare the above-mentioned Eurasian zonation and North American fusulinid zonation of Wilde (1990), it is possible to conclude that the Fusulinella bocki Zone approximately corresponds to DS-1 of the Desmoinesian. The Rauserites

quasiarcticus Zone can be correlated with MS-1 of the Missourian. According to their position in the section, the Protriticites ovatus-Praeobsoletes burkemensis, Obsoletes obsoletus-Protriticites pseudomontiparus and Montiparus montiparus zones correspond to DS-2, DS-3, DS-4, and DS- 5 zones of the Desmoinesian, respectively.

Recent data from the Arctic region support this correlation. In the lower and middle Kasimovian of Northern Timan and Kolguev Island Wedekindellina occurs (Remizova 1995; Davydov 1997b). This type of Wedekindellina in North America is known from the middle Desmoinesian. Also, occurrences of Plectofusulina and Oketaella in the lower Kasimovian of Kolguev Island were reported recently (Davydov 1997b). Both genera previously were known only in North American sections. Plectofusulina first 
appears in the middle Desmoinesian and range to Missourian. Oketaella ranges from Missourian to the Permian. Therefore Arctic sections are perhaps the key to solving the problem of correlation of Upper Carboniferous between Russian Platform and North America.

\section{CONCLUSIONS}

The recorded fusulinid assemblages in Moscovian/Kasimovian boundary beds in the Kolosseum section (Spitsbergen) correspond well to established fusulinid zones in the stratotype region of the Russian Platform.

Fusulinid assemblages in the Moscovian/Kasimovian boundary beds in Spitsbergen show a predominance of representatives of the Protriticites-Montiparus-Rauserites lineage. Representatives of the Praeobsoletes-Obsoletes-Triticites lineage in Spitsbergen occur later than in the stratotype region of the Russian Platform. The similarity of fusulinids from Moscovian/Kasimovian boundary beds in Spitsbergen, Cantabrian Mountains (Spain) and Carnic Alps (Austria) is compelling.

Moscovian/Kasimovian boundary beds in Spitsbergen and those in the adjacent areas (Northeast Greenland and Canadian Arctic) correlate well. The upper part of the Nansen Formation (units $\mathrm{H}-\mathrm{L}$ ) of the Sverdrup Basin, Canadian Arctic correlates with the Lower-Middle Kasimovian of the region of the Moscow Basin. The Moscovian/ Kasimovian boundary of Eurasia is approximately correlative with the basal DS-3 fusulinid zone of the Desmoinesian of North America. 


\section{ACKNOWLEDGMENTS}

We gratefully acknowledge IKU Petrolum Research (Trondheim) "Arctic Geo-Program" and "Fusulinid Project" and the support from the participating companies for the opportunity to study this material. V.I.D. thanks PRI for support in preparation of drafts and photographs. I.N acknowledges Saga Petroleum for support of drafts and drawing of figures. We thank Dale Kerner (Boise State University) for improvement of English. The reviews by two anonymous reviewers were also greatly appreciated.

\section{REFERENCES}

Alekseev, A. S., Goreva, N. V., Makhlina, M. K., Isakova, T. N., Barskov, I. S ., Lazarev, S. S., Kabanov, P. B., Lebedev, O. A., Shkolin, A. V., and L. I. Kononova. 1994. Biostratigraphy of Middle-Upper Carboniferous Boundary beds of Moscow Basin. Conference Proceedings "New biostartigraphic data of Paleozoic of the Russian Platform, Urals and Tian-Shan." Moscow, p. 7-8 [In Russian].

Chen-Tzin-Shi. 1963. About the morphology and systematic of Protriticites, Quasifusulinoides, and Obsoletus genera from Middle-Upper Carboniferous boundary beds. Questions of Micropaleontology, 7:71-84.

Barrick, J. E., Boardman, D. R., II. and Heckel, P.H.1996. Biostratigraphy across the Desmonesian-Missourian Stage boundary in North American Midcontinet, USA: Implication for defining the Middle-Upper Pennsylvanian Series boundary. Newslletters on Stratigraphy, 34(3):161-175.

Bensh, F. R. 1972. Stratigraphy and fusulinids of Upper Paleozoic of the Southern Fergana. Tashkent, "Fan, [In Russian].

Boardman, D. R., II, Heckel, P. H., Barrick, J. E., Nestell, M., and Peppers, R. A. 1990. Middle-Upper Pennsylvanian chronostratigraphic boundary in the Mid-Continent region of North America. Courier Forschungsinstitute Senckenberg, 130:319-337.

Brenckle, P. L. and Wahlman, G. P. 1993. Conilia, a new Upper Paleozoic pseudovidalinid foraminifer. Memoires Institut Geologique de l'Universite Catholique Louvain, 35:169-176.

Cutbill, J. L., and Challinior, A. 1965. Revision on the stratigraphical scheme for the Carboniferous and Permian rocks of Spitsbergen and Bjørnøya. Geological Magazine 102:418-439.

Dallmann, W. K., Gjelberg, J. G., Harland, W. B., Johannessen, E. P., Keilen, H. B., Lønøy, A., Nilsson, I., and Worsley, D. in press. Lithostratographical nomenclature of the Upper Palaeozoic rocks of Svalbard. Proposed by the Committee on the Stratigraphy of Svalbard (SKS), Subcommittee on Upper Paleozoic Stratigraphy. 
Davydov, V. I. 1984. Zonal subdivisions of the Upper Carboniferous of the SouthWestern Darvas (Central Asia). Bulletin Moscow Society of Natural studies, Geological series, 59:41-57. [In Russian].

Davydov, V. I. 1986. The fusulinids of Upper Carboniferous and Asselian of Lower Permian of the Southern Urals, p. 77-103. In Chuvashov, B. I., Leven, E. Y., and Davydov, V. I. (eds.), The Carboniferous/Permian boundary deposits of the Urals, Preurals and Central Asia. Nauka, Moscow.

Davydov, V. I. 1988. About a phylogenetic criterion of weighing specific features in foraminifer systematic (exemplified by fusulinids). Revue de Paleobiologie, Special Volume 2:47-55.

Davydov, V. I. 1990a. Zonal fusulinid subdivision of the Gzhelian in the Donets Basin and Predonets Trough. Problem of modern micropaleontology, Nauka, Leningrad, p. 5269. [In Russian].

Davydov, V. I. 1990b. Clarification of the origin and phylogeny of triticitids and the Middle and Upper Carboniferous boundary. Paleontological Journal, 24:13-25 [In Russian; translated in the Scripta Technica, Inc., 1991:39-51].

Davydov, V. I. 1992.Subdivision and correlation of the Donets Upper Carboniferous and Lower Permian deposits from fusulinid data. Sovetskaya Geologiya, 5:53-61. [In Russian].

Davydov, V. I. 1997a. Middle-Upper Carboniferous boundary: The problem of definition and correlation, p. 113-122. Podemski, M., Dybova-Jachowicz, S., Jureczka, J., and Wagner R. (eds.), Proceedings of the XIII International Congress on the Carboniferous and Permian. Polish Geological Institute, Warszawa, Poland.

Davydov, V. I. 1997b. Fusulind biostratigraphy of the Upper Paleozoic of Kolguev Island and Franz Josef Land, p. 40-59. Belonin, M.D. and Kirichkova A.I. (eds.), International Symposium "Biostratigraphy of Oil-Gaz bearing Basins". VNIGRI, St. Petersburg. [In Russian and English].

Dan'shin, B. M. 1947. Geological structure and economic deposits of Moscow and its vicinity. Moscow Society of Nature Studies, Moscow. [In Russian].

Dutkevich, G. A. 1934a. On the stratygraphy of the Middle Carboniferous of the Urals. Vsesoyuzniyi Neftianoi nauchno-issledovatel'skyi Geologorazvedochnyi Institute, Series A, 55:1-41.

Dutkevich, G. A. 1934b. Some new species of fusulinidae from the Upper and Middle Carboniferous of Verkhne-Chussovskye Gorodky of the Chussovaya River (western slope of the Middle Ural)]. Vsesoyuzniyi Neftianoi nauchno-issledovat. Geologorazvedochnyi Institute, Trudy serii A, 36:1-98.

Forbes, C. L. 1960. Carboniferous and Permian Fusulinidae from Spitsbergen. 
Paleontology, 2:210-225.

Groves, J. R. and Wahlman, G. P. 1997. Biostratigraphy and evolution of Late Carboniferous and Early Permian smaller foraminifers from Barents Sea (offshore Arctic Norway). Journal of Paleontology, 71:758-779.

Igo, H. and Okimura, Y. 1992. Carboniferous-Permian foraminifers of west Spitsbergen, p. 97-104. In: K. Nakamura (ed.), Investigation on the Upper Carboniferous-Upper Permian succession of West Spitsbergen 1989-1991. Hokkaido University Press, Sapporo, Japan.

Ivanov, A. P. 1926. Middle and Upper Carboniferous deposits of the Moscow area. Bulletin, Moscow Society of Natural Studying, Geological Series, 4 (1-2):138-178 [In Russian, p. 178-180 in French].

Ivanova, E. A. and Khvorova, I. V. 1955. Stratigraphy of the Middle and Upper Carboniferous of the western part of the Moscow syneclise. Transactions of the Paleontological Institute, 53:3-279. [In Russian].

Ivanova, E. A. and Rosovskaya, S. E. 1967. On biostratigraphy of the Upper Carboniferous of the Russian Platform based on the stratotype studies. Bulletin Moscow Society of Natural Studying, Geological Series, 42:86-99. [In Russian].

Kireeva, G. D. 1950. New fusulinid species from C-3-1 and C-3-3 limestones in the Donets Basin, p. 93-214. Rotai, A.P.(ed.), Materials on Stratigraphy and Paleontology of the Donets Basin. Khar'kov, Uglandekhizdat, USSR. [In Russian].

Konovalova, M. V. 1991. Stratigraphy and fusulinids of the Upper Carboniferous and Lower Permian of Timan-Pechora oil and gas-bearing province. Nedra, Moscow, 3-201. [In Russian].

Krainer, K. and Davydov, V.I., 1998. Facies and biostratigraphy of the Late Carboniferous/Early Permian sedimentary sequence in the Carnic Alops (Austria/ltaly), in Crasquin-Soleau,S., Izart, D., and DeWever, P. (eds) Peri-Tethys: stratigraphic correlation 2, Geodiversitas, vol. 20, no 4, p. 643-662.

Lee, J. S. 1927. Fusulinidae of North China. Paleontologica Sinica, Series B, 4: 1-172.

Lee, J., Chen, S., and Chu, S. 1930. Huanglung Limestone and its fauna. Memoirs of the National Research Institute of Geology, 9:85-144.

Makhlina, M. K., Isakova, T. N., and Julitova, V. E. 1984. The Upper Carboniferous in the region of the Moscow Basin, p. 5-14. In: Menner, V. V. and Grigorieva, A. D. C. (eds.), The Upper Carboniferous of the USSR. Transactions of the Interdepartmental Startigraphic Committee of the USSR, volume 13. [In Russian].

Merrill, G. K.1975. Pennsylvanian conodont biostratigraphy and paleoecology of northwestern Illinois. Geological Society of America, Microform Publication, 3:1-129. 
Möller, V. von. 1878. Die spiral-gewundenen Foraminiferen des russischen Kohlenkalkes. Zapiski Imperatorskoi Akademii Nauk, Series 7(25)1-147. [In Russian and German].

Nilsson, I. 1988. Carboniferous and Permian Fusulinids on the Nordfjorden Block, Spitsbergen (Svalbard). Unpublished M.Sc. thesis, University of Oslo, Olso, Norway.

Nilsson, I. 1993. Upper Paleozoic fusulinid stratigraphy of the Barents Shelf and surrounding areas. Unpublished Ph.D. Thesis, University of Tromsø, Troms $\varnothing$, Norway.

Nilsson, I. and Davydov, V. I. 1992. Upper Carboniferous (Kasimovian-Gzhelian) and Lower Permian (Asselian-Sakmarian) fusulinid stratigraphy in central Spitsbergen, Arctic Norway. IKU Petroleumsforskning a.s., Report No 23.1356.00/07/92, 185 p.

Nilsson, I. and Davydov, V. I. 1997. Fusulinid biostratigraphy in Upper Carboniferous (Gzhelian) and Lower Permian (Asselian-Sakmarian) successions of Spitsbergen, Arctic Norway: Permophiles, 30:18-24.

Putrja, F. S. 1939. The materials to stratigraphy of Upper Carboniferous of Eastern part of Donets Basin. Materialy po geologii i poleznym iskopaemym, Sbornik 10:97-156. [In Russian].

Putrja, F. S. 1948. The Protriticites - new genus of fusulinids. Transactions of L'vov University, Series Paleontological, Issue 1:89-96. [In Russian].

Rauser-Chernousova, D. M., Belyaev, G. M., and Reitlinger, E. A. 1936. Upper Paleozoic foraminifers of the Pechora area. Transactions of Polar Commission of Academy of Sciences of USSR 28:152-232. [In Russian].

Rauser-Chernousova, D. M., Belyaev, G., and Reitlinger, E. 1937. The Upper Paleozoic Foraminifera of the Pechora area. Transactions of Polar Commission of Academy of Sciences of USSR 28:159-232. [In Russian].

Rauser-Chernousova, D. M., Gryzlova, N. D., Kireeva, G. D., Leontovich, G. E., Safonova, T. P., and Chernova, E. I. 1951. Middle Carboniferous fusulinids in the Russian Platform and adjacent area. Nauka, Moscow. [In Russian].

Rauser-Chernousova, D. M. and Reitlinger, E. A. 1954. Biostratigraphic distribution of foraminifers in the Middle Carboniferous of the southern part of the Moscow Basin, p. 7120. In: Menner, V. V. (ed.), Regional stratigraphy of the USSR, Volume 2. Nauka, Moscow. [In Russian].

Rauser-Chernousova, D. M., and Scherbovich, S. F. 1974. Some problems of the Kasimovian based on fusulinid study. News of Academy of Sciences of the USSR, Geological Series, 6:91-103. [In Russian].

Remizova, S. T. 1995. Foraminifers and biostratigraphy of Upper Carboniferous of the Northern Timan. Uralian branch of Russian Academy of Sciences, KOMI Scientific 
Center, Syktyvkar. [In Russian].

Remizova, S. T. 1997. Fusulinid correlation of Middle-Late Carboniferous boundary beds of Northern Timan, Russia, with the North Euramerican Province, p. 115-118. In Ross, C. A., Ross J. R. P., and Brenckle, P. L. (eds.), Late Paleozoic Foraminifera; their biostratigraphy, evolution and paleoecology; and the Mid-Carboniferous boundary. Cushman Foundation for Foraminiferal Research, Special Publication 36.

Rosovskaya, S. E. 1950. The Triticites genus, its development and stratigraphic significance. Transaction of Paleontological Institute of Academy Sciences of the USSR, 26:3-79. [In Russian].

Rosovskaya, S. E. 1952. Fusulinids of the Upper Carboniferous and Lower Permian of the Southern Urals. Transactions of Paleontological Institute of Academy Sciences of the USSR, 40:5-51. [In Russian].

Ross, C. A. 1995. Permian Fusulinaceans, p. 167-185. In Scholle, P. A., Peryt, T. M., and Ulmer-Scholle, D. S (eds.) The Permian of Northern Pangea. Volume 1: Paleogeogaphy, Paleoclimates, Stratigraphy: Springer-Verlag, Berlin.

Ross, C. A. and Ross J. R. P. 1987. Biostratigraphic zonation of Late Paleozoic depositional sequences. Cushman Foundation for Foraminiferal Research, Special Publication, 24:151-168.

Rui Lin, Ross, C.A., and Nassichuk, W. W. 1991. Upper Moscovian (Desmoinesian) fusulinaceans from the type section of the Nansen Formation, Ellesmere Island, Arctic Archipelago. Geological Survey of Canada Bulletin, 418:1-121.

Rui Lin, and Nassichuk, W. W. 1994. Fusulinaceans at the Middle/Upper Pennsylvanian (Desmoinesian/Missourian) boundary in the Canadian Arctic Archipelago. Pangea: Global environments and resources. Canadian Society of Petroleum Geologists, Memories, 17:907-926.

Ruzhentsev, V. E. 1974. Late Carboniferous ammonoids of the Russian Platform and Preurals. Paleontological Journal, 3:32-46. [In Russian].

Scherbakov, O. A., Shestakova, M. F., Scherbakova, M. V., Kitaev, P.M., and Stepanaitis, N.E. 1984: Zonal subdivisions of the Carboniferous of the Western slope of the Central Urals. Transactions of 8th International Congress on the Carboniferous, 2:270-277. [In Russian].

Sossipatrova, G. P. 1967. Upper Paleozoic foraminifera of Spitsbergen, p. 1-238. In Sokolov, V. N. (ed.), Stratigraphy of Spitsbergen. Institute Geologii Arktiki, Leningrad. [In Russian, English translation available from the Lending Division of the British Library Board, 1977, p. 125-163).

Villa, E. O., Ginkel, A. C.van, Leyva, F., Martinez-Chacon, M. L., Mendez, C., Rodrigues-Gonzalez, R. M., Rodriguez, S., and Sanchez De Posada, L. C. 1993. Fossil 
contents of the Moscovian-Kasimovian boundary in a section of the Picos de Europa area (Carboniferous, NW Spain). Compte Rendu XII International Congress on the Carboniferous and Permian, 2:385-406.

Villa, E. O., Davydov, V. I., Konovalova, M. V., and Remizova, S. T. 1994. Studies on the base of the Protriticites zone. A report on SCCS Project 5. Annales de la Societe Geologique de Belgique, 116:323-331.

Villa, E. O., Alekseev, A. S., Barskov, I. S., Coquel, P., Davydov, V. I., Ginkel, A. C., van, Goreva, N. V., Isakova, T. N., Kabanov, P. B., Kononova, L. I., Lazarev, S. S., Lebedev, O. A., Makhlina, M. K., Mamet, B., Martinez-Chacon, M. L., Mendez, C., Rodrigues-Gonzalez, R. M., Rodriguez, S., Sanchez De Posada, L. C., and Shkolin, A.,V. 1997. Paleontological analysis and comparison of the Moscovian/Kasimovian boundary beds in the Moscow Basin (Russia) and in the Cantabrian Mountains (Spain). Proceedings of the XIII International Congress on the Carboniferous and Permian, Warszawa, p. 113-122.

Volozhanina, P. P. 1962. Fusulinids of Upper Carboniferous of Timan-Pechora area. Questions of Micropaleontology 6:16-145. [In Russian].

Wahlman, G. P., Verville, G. J., and Sanderson, G. A. 1997. Biostratigraphic significance of the fusulinacean Protriticites in the Desmoinesian (Pennsylvanian) of the Rocky Mountains, Western U.S.A., p. 163-168. In Ross, C. A., Ross, J. R. P., and Brenckle P. L. (eds), Late Paleozoic Foraminifera; their biostratigraphy, evolution and paleoecology; and the Mid-Carboniferous boundary. Cushman Foundation for Foraminiferal Research, Special Publication, 36:.

Wilde, G. L. 1990. Practical fusulinid zonation: The species concept with Permian basin emphasis. West Texas Geological Society Bulletin, 29:5-34. 
Table 1. Upper Moscovian and Kasimovian fusulinid zonal succession in Eurasia.

\begin{tabular}{|l|l|l|}
\hline Zone & Age & Locality \\
\hline $\begin{array}{l}\text { Rauserites } \\
\text { quasiarcticus }\end{array}$ & late Kasimovian & $\begin{array}{l}\text { Dorogomilovian, Perkhurovskaya Fm. } \\
\text { in the Moscow Basin }\end{array}$ \\
\hline $\begin{array}{l}\text { Montiparus } \\
\text { montiparus }\end{array}$ & middle Kasimovian & $\begin{array}{l}\text { Khamovnicheian, Ratmirovskaya and } \\
\text { Neverovskaya Fms. in the Moscow } \\
\text { Basin }\end{array}$ \\
\hline $\begin{array}{l}\text { Protriticites } \\
\text { pseudomontiparus- } \\
\text { Obsoletes } \\
\text { obsoletus }\end{array}$ & early Kasimovian & $\begin{array}{l}\text { Krevyakinian, Suvorovskaya and } \\
\text { Voskresenskaya Fms. in the Moscow } \\
\text { Basin }\end{array}$ \\
\hline $\begin{array}{l}\text { Protriticites ovatus- } \\
\text { Praeobsoletes } \\
\text { burkemensis }\end{array}$ & late Myachkovian & $\begin{array}{l}\text { Peskovskaya Fm. in the Moscow } \\
\text { Basin }\end{array}$ \\
\hline Fusulinella bocki & early Myachkovian & Novlinskaya Fm. in the Moscow Basin \\
\hline
\end{tabular}


Table 2. Fusulinid zones of Desmoinesian (DS) and Missourian (MS) in USA by Wilde (1990).

\begin{tabular}{|l|l|}
\hline Zone & Characteristic fauna \\
\hline $\begin{array}{l}\text { 8. Zone of Eowaeringella and Triticites } \\
\text { of the Missourian (MC1). }\end{array}$ & Eowaeringella, Triticites \\
\hline 7. Upper zone of Fusulina (DS5): & "Fusulina cylindrica" group. \\
\hline 6. Lower zone of Fusulina (DS4): & $\begin{array}{l}\text { Fusulina megista, F. acme, F. exima, } \\
\text { Bartramella bartrami, Protriticites spp., } \\
\text { Praeobsoletes spp. }\end{array}$ \\
\hline 5. Upper zone of Beedeina (DS3): & $\begin{array}{l}\text { Beedeina girtyi, B. illinoisensis, B. } \\
\text { similis, B. haworthi, Bartramella } \\
\text { bartrami, Protriticites spp. } \\
\text { Plectofusulina sp. }\end{array}$ \\
\hline 4. Middle zone of Beedeina (DS2b): & $\begin{array}{l}\text { Beedeina novamexicana, B. distenta, } \\
\text { B. levicula }\end{array}$ \\
\hline $\begin{array}{l}\text { 3. Upper zone of Wedekindellina } \\
\text { (DS2a): }\end{array}$ & $\begin{array}{l}\text { Wedekindellina euthysepta, W. } \\
\text { henbesty, W. excentrica, W. magna, } \\
\text { W. ellipsoides }\end{array}$ \\
\hline 2. Lower zone of Beedeina (DS1b): & Beedeina eurytensis, B. leei, B. pumila \\
\hline $\begin{array}{l}\text { 1. Lower zone of Wedekindellina } \\
\text { (DS1a): }\end{array}$ & $\begin{array}{l}\text { Wedekindellina euthysepta, } \\
\text { Fusulinella iowensis, F. matura }\end{array}$ \\
\hline
\end{tabular}


Table 3. Correlation of Middle/Upper Carboniferous fusulinids in Eurasia and North America

\begin{tabular}{|l|l|}
\hline Eurasia & North America \\
\hline $\begin{array}{l}\text { Rauserites quasiarcticus } \\
\text { (Dorogomilovian) }\end{array}$ & $\begin{array}{l}\text { MS-1 First zone of Triticites and } \\
\text { Eowaeringella }\end{array}$ \\
\hline $\begin{array}{l}\text { Montiparus montiparus } \\
\text { (Khamovnichenian) }\end{array}$ & $\begin{array}{l}\text { DS-5,4 Upper zone of Fusulina and lower } \\
\text { zone of Fusulina }\end{array}$ \\
\hline $\begin{array}{l}\text { Protriticites pseudomontiparus- } \\
\text { Obsoletes obsoletus (Krevyakinian) }\end{array}$ & $\begin{array}{l}\text { DS-2b,3 Middle-Upper zone Beedeina and } \\
\text { Upper zone of Wedekindellina }\end{array}$ \\
\hline $\begin{array}{l}\text { Protriticites ovatus- } \\
\text { Praeobsoletes burkemensis } \\
\text { (late Moscovian, late Myachkovian) }\end{array}$ & $\begin{array}{l}\text { DS-1b,2a Lower zone of Beedeina: } \\
\text { Beedeina eurytensis, B. leei, B. pumila }\end{array}$ \\
\hline $\begin{array}{l}\text { Fusulinella bocki (late Moscovian, } \\
\text { early Myachkovian) }\end{array}$ & $\begin{array}{l}\text { DS-1a Lower zone of Wedekindellina: } \\
\text { Wedekindellina euthysepta, Fusulinella } \\
\text { iowensis, F. matura }\end{array}$ \\
\hline
\end{tabular}


Figure 1. Map of Spitsbergen.

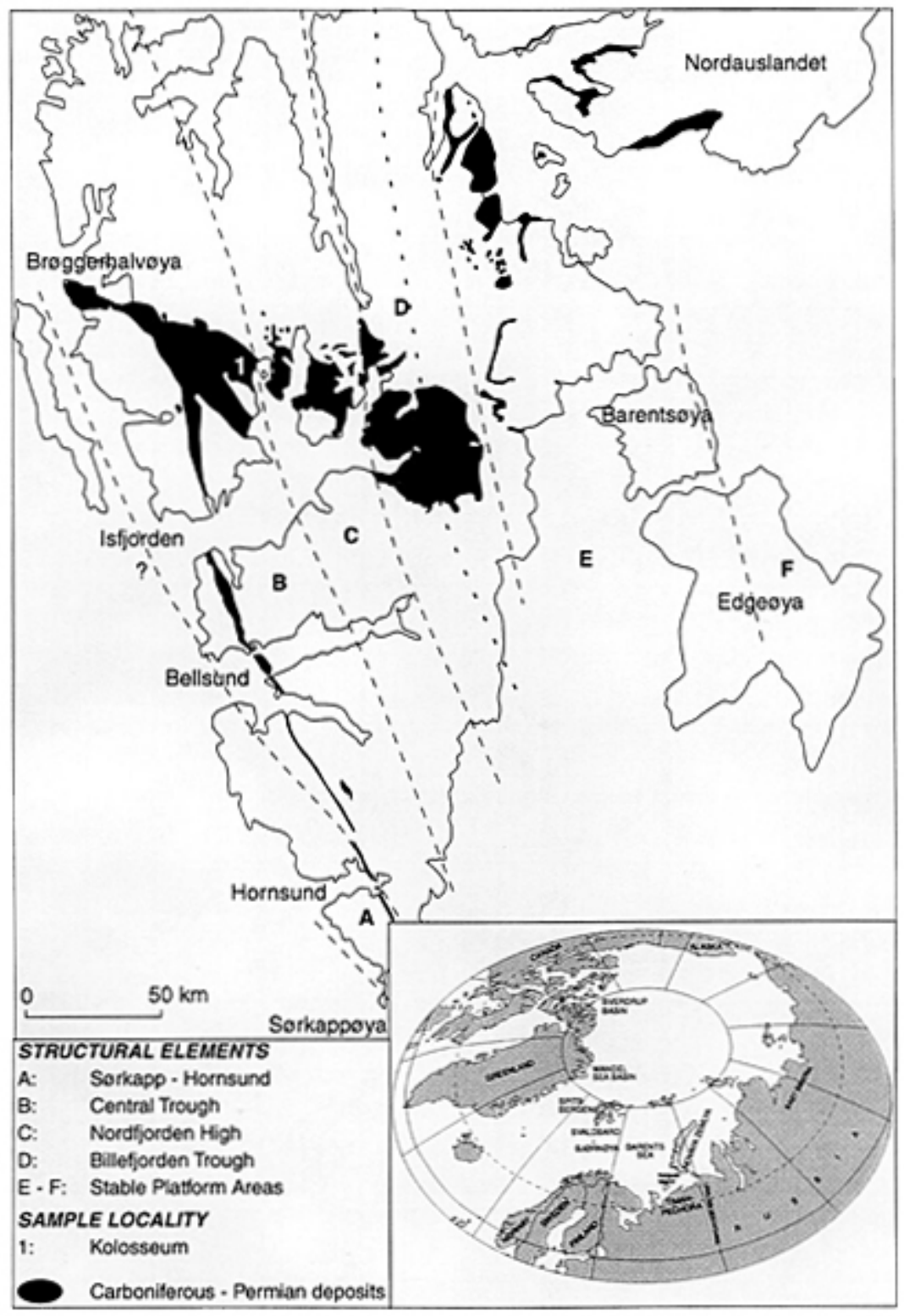


Figure 2. Lithostratigraphy of central Spitsbergen.

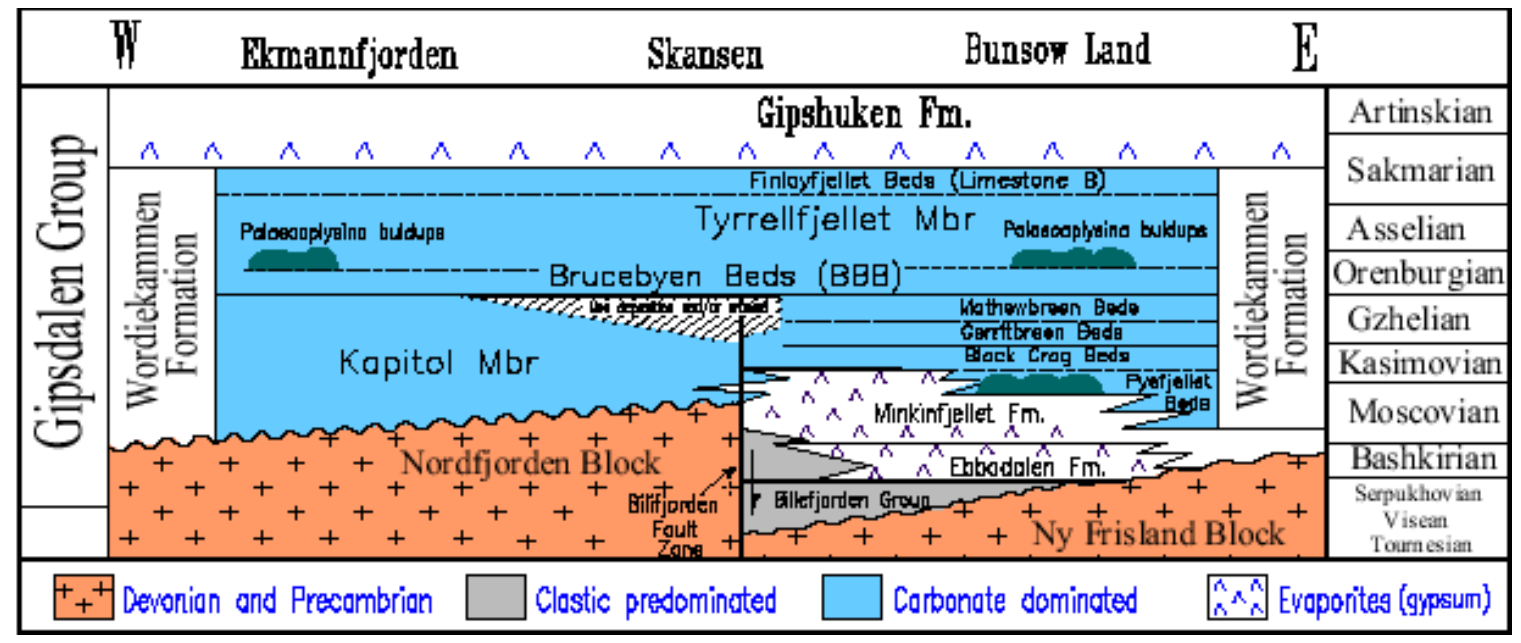


Figure 3. Kolosseum section, with samples marked.

\section{Kolosseum}

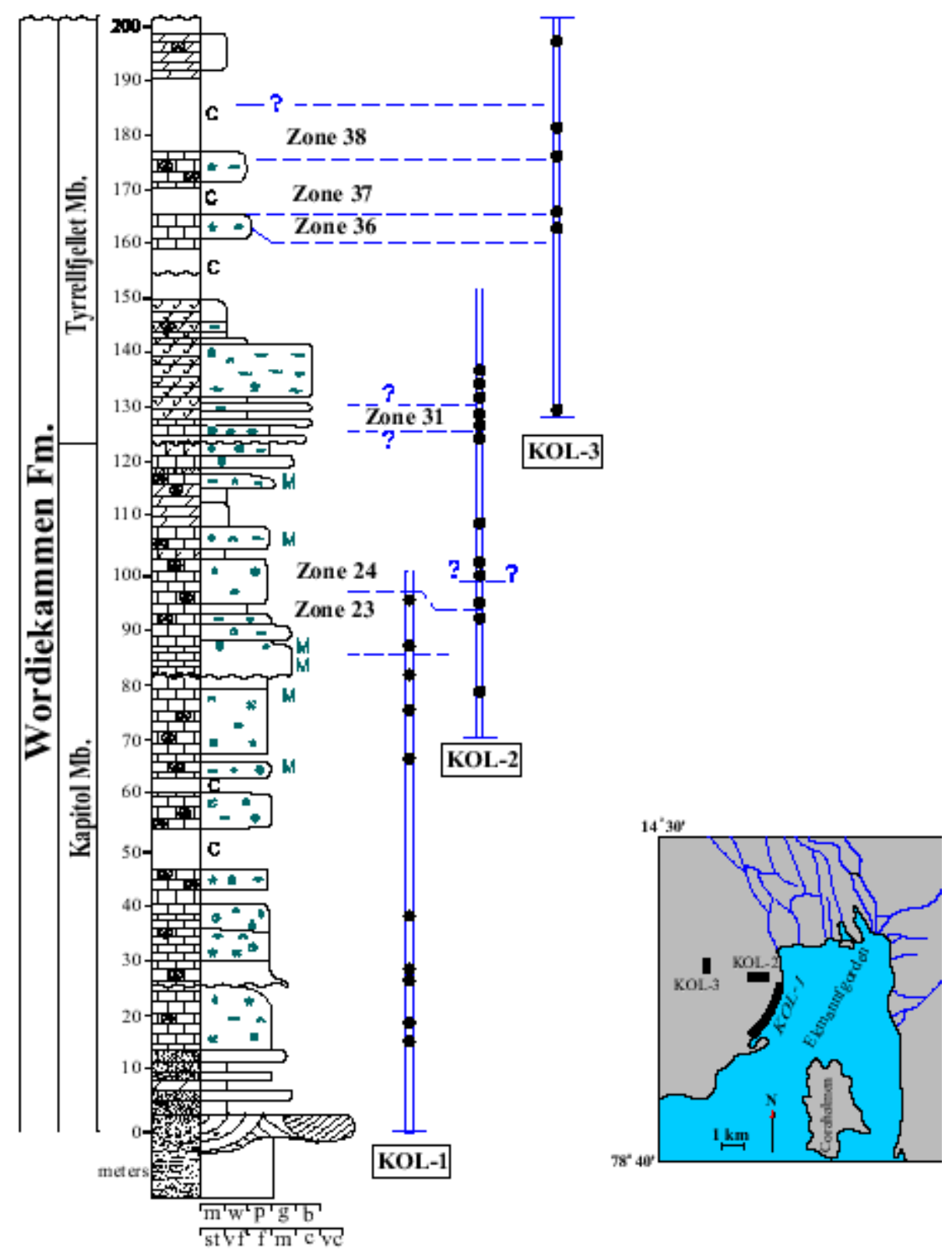


Figure 4. Fusulinid distributions in the Kolosseum section. All specimens from this collection are housed in the Oslo Paleontological Museum (PMO), collection number 43865 .

\begin{tabular}{|c|c|c|c|c|c|c|c|c|c|c|c|}
\hline \multirow{2}{*}{\begin{tabular}{|c|} 
Fusulinid Zonation \\
Taxa $\backslash$ Sample
\end{tabular}} & \multicolumn{4}{|c|}{$\begin{array}{l}\text { Fusulinella } \\
\text { bocki } \\
\text { Zone }\end{array}$} & \multicolumn{2}{|c|}{$\begin{array}{l}\text { Protriticites ex. gr. } \\
\text { ovatus } \\
\text { Quasifusulinoides } \\
\text { quasifusulinoides } \\
\text { Zone }\end{array}$} & \multicolumn{4}{|c|}{$\begin{array}{l}\text { Protriticites } \\
\text { pseudomonti } \\
\text { parus } \\
\text { Obsoletes } \\
\text { obsoletus } \\
\text { Zone }\end{array}$} & \multirow{2}{*}{ 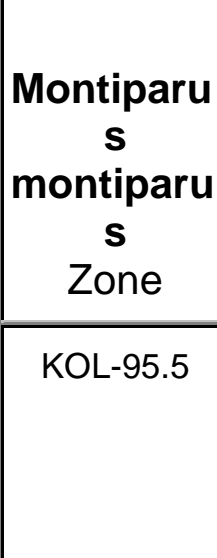 } \\
\hline & \begin{tabular}{|l|}
$\mathrm{K}$ \\
$\mathrm{OL}$ \\
- \\
28 \\
.3
\end{tabular} & \begin{tabular}{|l|}
$\mathrm{K}$ \\
$\mathrm{OL}$ \\
- \\
29 \\
.5
\end{tabular} & $\begin{array}{l}\mathrm{K} \\
\mathrm{OL} \\
- \\
38 \\
.0\end{array}$ & \begin{tabular}{|c|}
$\mathrm{K}$ \\
$\mathrm{OL}$ \\
- \\
66 \\
.0
\end{tabular} & KOL-76.0 & KOL-79.0 & $\begin{array}{c}\text { KO } \\
\mathrm{L}- \\
81 . \\
0\end{array}$ & $\begin{array}{c}\mathrm{KO} \\
\mathrm{L}- \\
82 . \\
0\end{array}$ & $\begin{array}{c}\text { KO } \\
\text { L- } \\
87 . \\
5\end{array}$ & $\begin{array}{c}\mathrm{KO} \\
\mathrm{L}- \\
91 . \\
5\end{array}$ & \\
\hline 1. Fusulinella bocki & $x$ & & $x$ & & & $x$ & $x$ & & & & \\
\hline $\begin{array}{l}\text { 2. Fusulinella } \\
\text { helenae }\end{array}$ & $x$ & & & & & $x$ & $x$ & & & & \\
\hline $\begin{array}{l}\text { 3. Wedekindellina } \\
\text { dutkevichi }\end{array}$ & $x$ & $x$ & $x$ & & & & & & & & \\
\hline $\begin{array}{l}\text { 4. Beedeina } \\
\text { elshanica }\end{array}$ & & $x$ & & & & & & & & & \\
\hline $\begin{array}{l}\text { 5. Beedeina } \\
\text { paradistenta }\end{array}$ & & $x$ & & & & & & & & & \\
\hline $\begin{array}{l}\text { 6. Beedeina } \\
\text { samarica }\end{array}$ & & $x$ & $x$ & & & & & & & & \\
\hline $\begin{array}{l}\text { 7. Fusulinella cf. } \\
\text { bocki }\end{array}$ & & $x$ & & & & $x$ & $x$ & & & & \\
\hline $\begin{array}{l}\text { 8. Fusulinella } \\
\text { mosquensis }\end{array}$ & & $x$ & & & & & & & & & \\
\hline $\begin{array}{l}\text { 9. Beedeina } \\
\text { distenta }\end{array}$ & & & $x$ & & & & & & & & \\
\hline $\begin{array}{l}\text { 10. Eowaeringella? } \\
\text { sp. }\end{array}$ & & & $x$ & & & & & & & & \\
\hline
\end{tabular}




\begin{tabular}{|c|c|c|c|c|c|c|c|}
\hline 11. Fusiella typica & $x$ & & $x$ & & & & \\
\hline 12. Fusulinella sp. & $x$ & & & $x$ & & & \\
\hline $\begin{array}{l}\text { 13. Neostraffella } \\
\text { sphaeroidea }\end{array}$ & $x$ & & & & & & \\
\hline $\begin{array}{l}\text { 14. Protriticites ex } \\
\text { gr. globulus }\end{array}$ & $x$ & & & & & & \\
\hline $\begin{array}{l}\text { 15. Protriticites? } \\
\text { sp. }\end{array}$ & $x$ & & & $x$ & & & \\
\hline $\begin{array}{l}16 . \\
\text { Pseudofusulinella? } \\
\text { eopulchra }\end{array}$ & $x$ & $x$ & $x$ & $x$ & & & $x$ \\
\hline $\begin{array}{l}17 . \\
\text { Quasifusulinoides? } \\
\text { eopulchra }\end{array}$ & $x$ & & & & & & \\
\hline $\begin{array}{l}18 . \\
\text { Quasifusulinoides? } \\
\text { intermedius }\end{array}$ & $x$ & & & & & & \\
\hline $\begin{array}{l}19 . \\
\text { Quasifusulinoides? } \\
\text { kolensis }\end{array}$ & $x$ & & & & & & \\
\hline $\begin{array}{l}20 . \\
\text { Pseudofusulinella? } \\
\text { pulchra }\end{array}$ & $x$ & & $x$ & & $x$ & $x$ & \\
\hline $\begin{array}{l}\text { 21. Fusulina } \\
\text { mosquensis }\end{array}$ & & $x$ & $x$ & & & & \\
\hline $\begin{array}{l}\text { 22. Protriticites aff. } \\
\text { sphaericus }\end{array}$ & & & $x$ & & & $x$ & $x$ \\
\hline $\begin{array}{l}\text { 23. Protriticites ex } \\
\text { gr. ovatus }\end{array}$ & & & $x$ & & & & $x$ \\
\hline $\begin{array}{l}24 . \\
\text { Pseudofusulinella? } \\
\text { ylychensis }\end{array}$ & & & $x$ & & & & \\
\hline
\end{tabular}




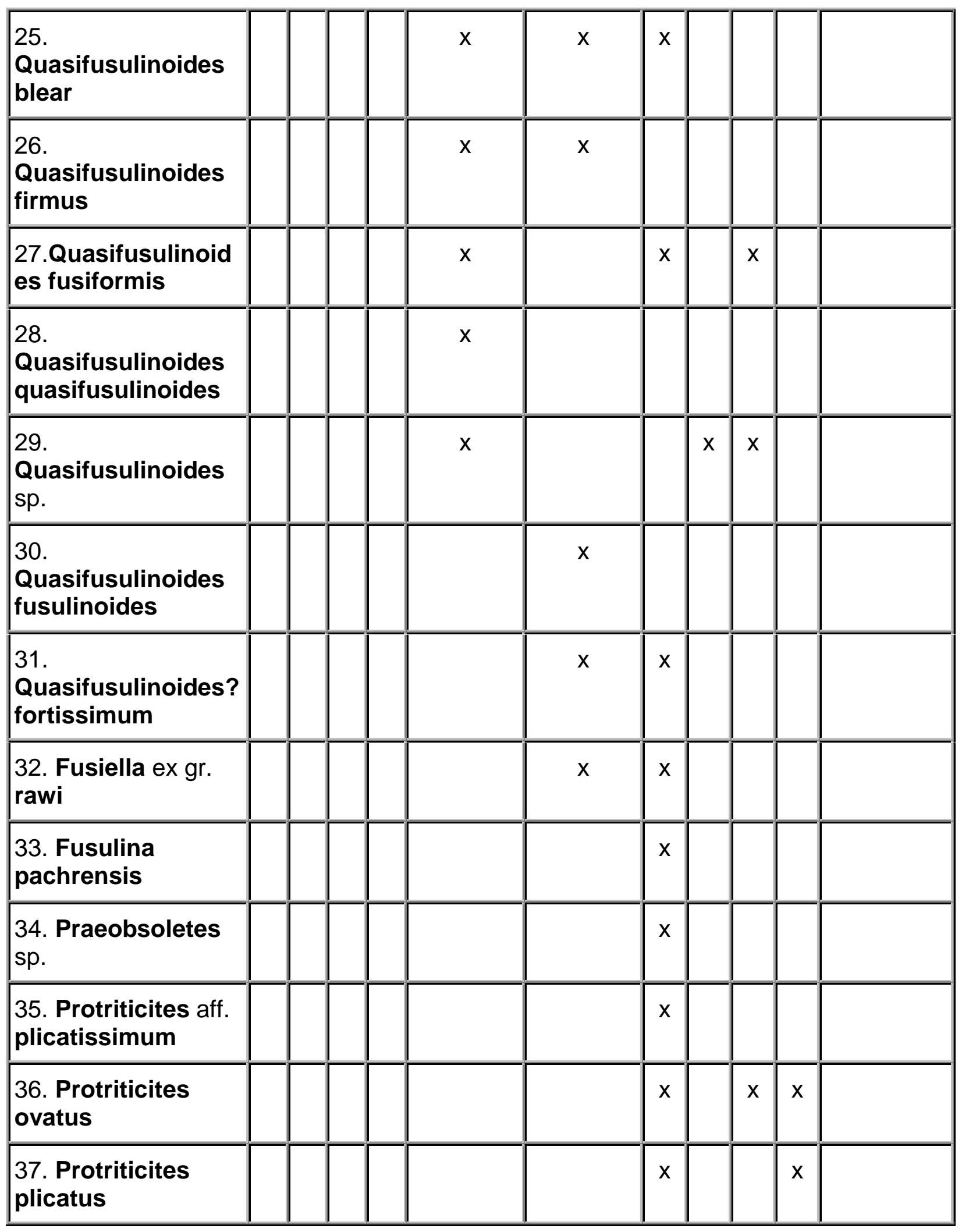




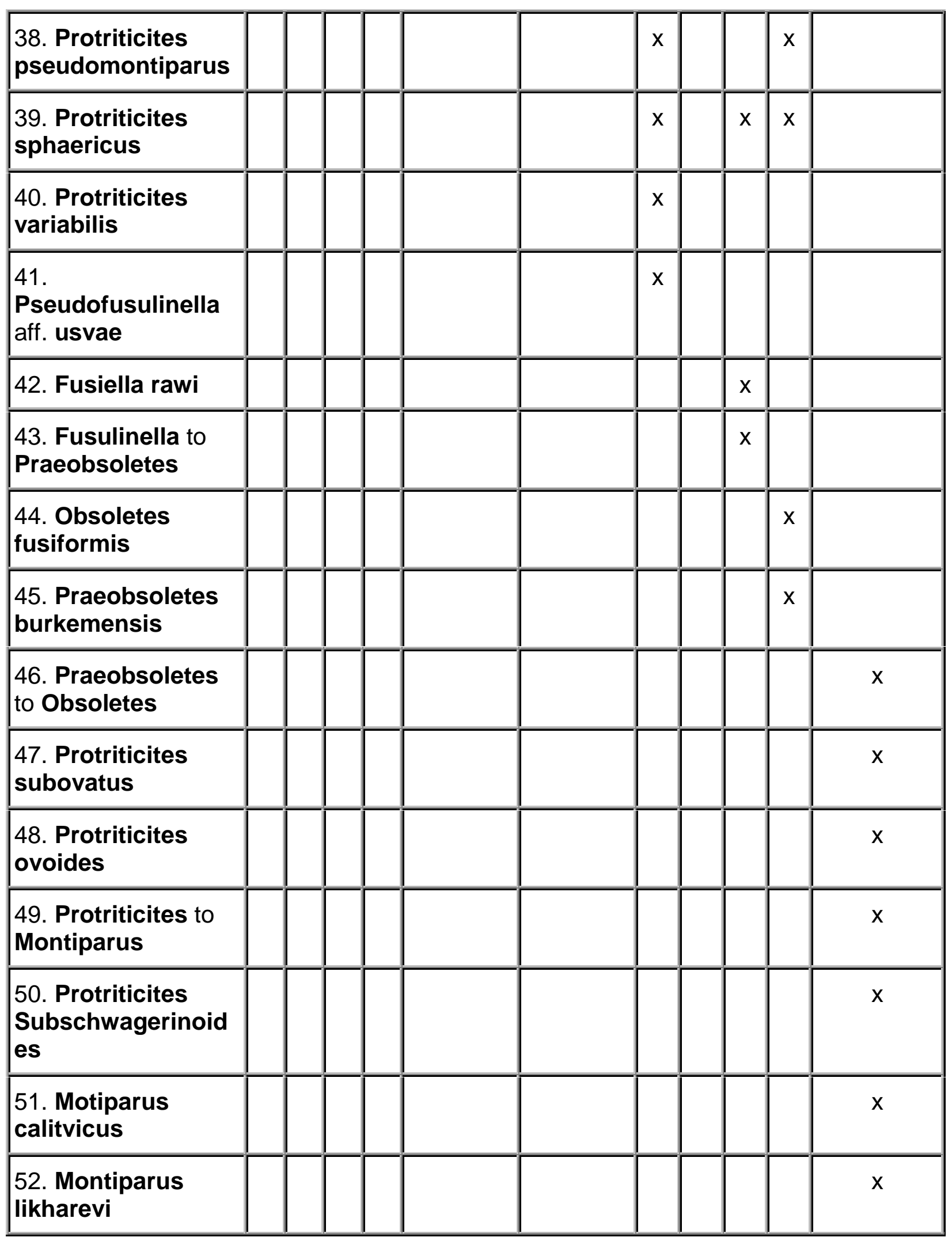




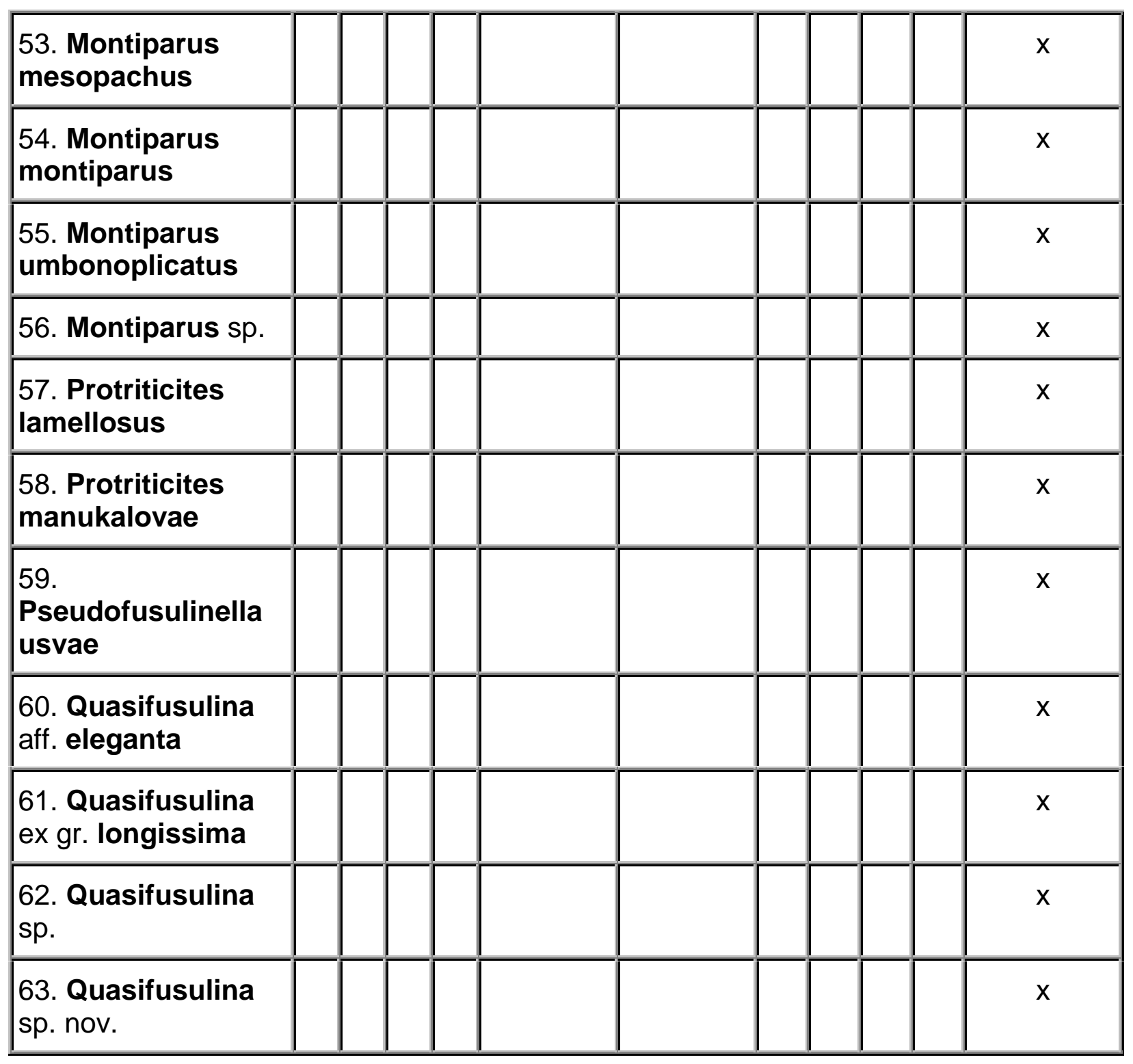


Figure 5.1-20. Fusulinid assemblage of Fusulinella bocki Zone, all figures from bed $38.5 \mathrm{~m}$. 1. Fusiella cf. typica Lee and Chen 1930, scale bar $=88 \mathrm{~mm}$, (PMO43865/14a), oblique section; 2-4. Neostaffella sphaeroidea (Ehrenberg em. Moeller 1878), 2. scale bar $=88 \mathrm{~mm}$, axial section of young specimen, (PMO-43865/14a); 3. scale bar $=44 \mathrm{~mm}$, oblique axial section, (PMO-43865/22a); 4 . scale bar $=66 \mathrm{~mm}$, oblique axial section, (PMO-43865/14a). 5. Neostaffella cf. paradoxa (Dutkevich $1934 \mathrm{a})$, scale bar $=88 \mathrm{~mm}$, oblique axial section, (PMO-43865/22a). 6-7.

Wedekindellina uralica (Dutkevich 1934b), 6. scale bar $=44 \mathrm{~mm}$, axial sections, (PMO43865/14a); 7. scale bar $=88 \mathrm{~mm}$, axial section, $(\mathrm{PMO}-43865 / 9 \mathrm{a})$. 8. Wedekindellina subovata Safonova 1951, scale bar $=88 \mathrm{~mm}$, near axial section, (PMO-43865/18a). 9 . Beedeina samarica (Rauser and Belyaev in Rauser-Chernousova, Belyaev, and Reitlinger 1937), scale bar $=33 \mathrm{~mm}$, oblique axial section, (PMO-43865/10a). 10. Beedeina elegans (Rauser 1951), scale bar $=33 \mathrm{~mm}$, near axial section, (PMO43865/4a). 11-14. Quasifusulinoides? kolensis (Nilsson $1988 \mathrm{msc}$.), scale bar = $22 \mathrm{~mm}$, axial sections 11. (PMO-43865/21a); 12. (PMO-43865/12a); 13. (PMO$43865 / 1 \mathrm{a}) ; 13 \mathrm{a}$. scale bar $=88 \mathrm{~mm}$, enlargement of figure $6-13$, wall structure with tectum, gray diaphanotheca and dark inner tectorium; 14. (PMO-43865/18a); 14a, scale bar $=88 \mathrm{~mm}$, enlargement of figure 6-14. 15-16. Pseudofusulinella? pulchra (Rauser and Belyaev in Rauser-Chernousova, Belyaev, and Reitlinger 1937), scale bar $=33 \mathrm{~mm}$ 15. near axial section, (PMO-43865/8a); 16. axial section, (PMO-43865/6a). 17-18. Pseudofusulinella? eopulchra (Rauser 1951), scale bar $=33 \mathrm{~mm}$, both axial section 17. (PMO-43865/3a); 18. (PMO-43865/14a). 19-20. Fusulinella bocki (Moeller 1878) 19. scale bar $=66 \mathrm{~mm}$, axial section, $(\mathrm{PMO}-43865 / 10 \mathrm{a}) ; 20$. scale bar $=33 \mathrm{~mm}$, oblique axial section, (PMO-43865/6a); 20a enlargement of figure $6-20$, scale bar $=110 \mathrm{~mm}$, typical Fusulinella wall structure with tectum, light diaphanotheca and dark inner and outer tectorium. 


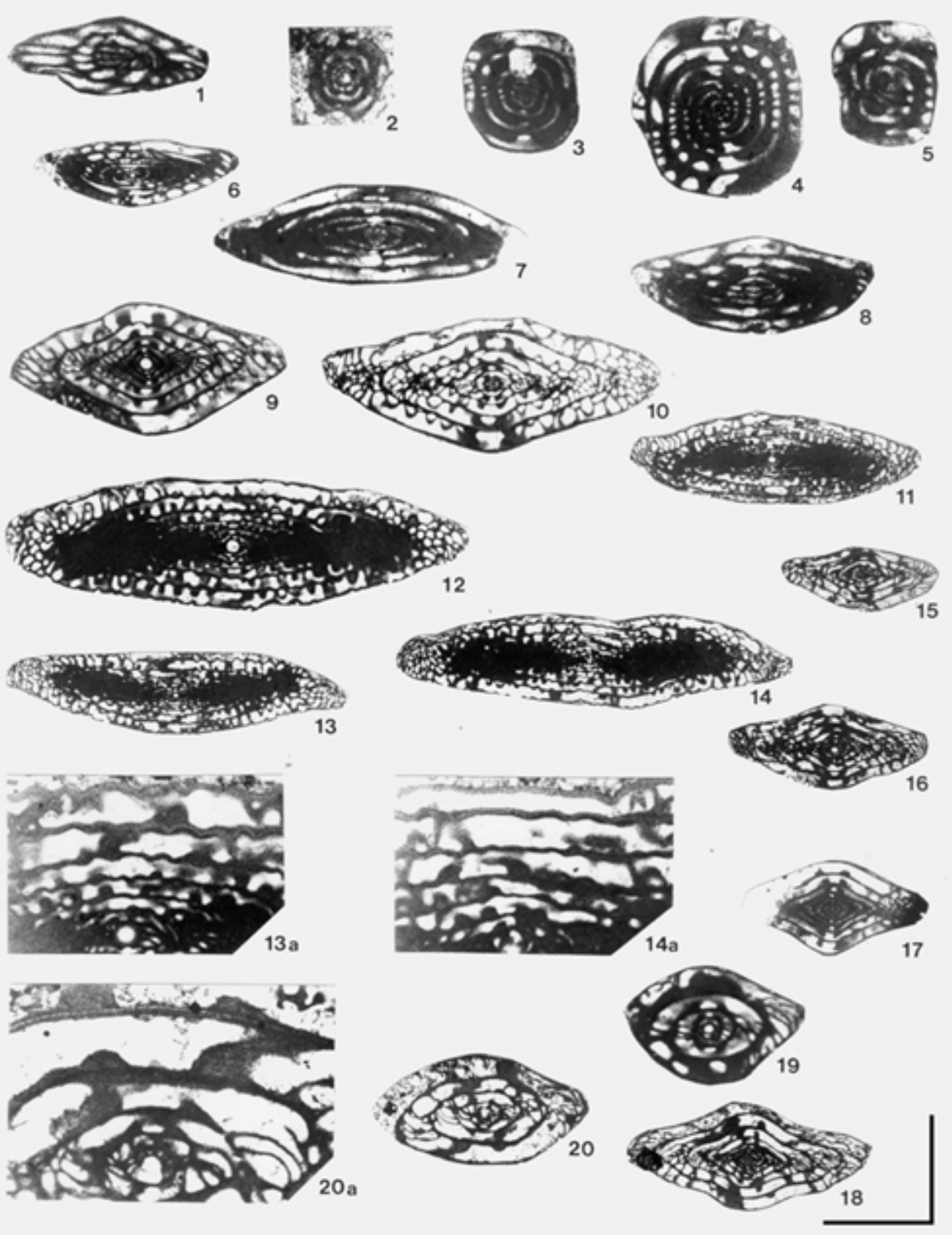


Figure 6.1-18. Fusulinid assemblage of Protriticites ex gr. ovatus-Quasifusulinoides quasifusulinoides Zone. 1. Fusiella praelancetiformis Safonova 1951, scale bar = $88 \mathrm{~mm}$, axial section, bed $76.0 \mathrm{~m}$, (PMO-43859/A1a). 2. Fusiella praecursor Rauser 1951 , scale bar $=88 \mathrm{~mm}$, axial section, bed $76.0 \mathrm{~m}$, (PMO-43859/1a). 3. Fusiella typica Lee et Chen 1934, scale bar $=110 \mathrm{~mm}$, axial section, bed $76.0 \mathrm{~m}$, (PMO-43859/2a). 4. Beedeina mosquensis (Rauser 1951), scale bar $=22 \mathrm{~mm}$, axial section, bed $66.0 \mathrm{~m}$, (PMO-43860/1a); 4a, enlargement of figure 7-4, scale bar $=88 \mathrm{~mm}$, typical Beedeina wall structure with tectum, light diaphanotheca and dark inner and outer tectorium. $\mathbf{5 .}$ Quasifusulinoides firmus (Rauser 1951), scale bar $=22 \mathrm{~mm}$, axial section of incomplete specimen, bed $76.0 \mathrm{~m}$, (PMO-43859/B1a); 5a, enlargement of figure 7-5, scale bar $=88 \mathrm{~mm}$, wall structure with tectum, indistinct diaphanotheca and dark inner tectorium with well developed pores. 6-7. Quasifusulinoides fusiformis (Rosovskaya, 1952), scale bar $=22 \mathrm{~mm}$, both axial sections, 6 , bed $76.0 \mathrm{~m}$, (PMO43859/9a); 7, bed $79.0 \mathrm{~m}$, (PMO-43858/12a). 8-9. Pseudofusulinella? eopulchra (Rauser 1951), scale bar $=22 \mathrm{~mm}$, both axial sections, 8 , bed $79.0 \mathrm{~m}$, (PMO-43858/1a); 9, bed $76.0 \mathrm{~m}$, (PMO-43858/D1a). 10. Fusulinella helenae Safonova 1951, scale bar = $33 \mathrm{~mm}$, near axial section, bed $79.0 \mathrm{~m}$, (PMO-43858/14a); 10a, enlargement of figure 710 , scale bar $=110 \mathrm{~mm}$, wall structure with tectum, diaphanotheca and dark inner and outer tectorium. 11-12. Fusulinella bocki Moeller, 1878 , scale bar $=33 \mathrm{~mm}$, both axial sections, bed $79.0 \mathrm{~m}, 11$, (PMO-43858/25a); 12, (PMO-43858/6a). 13. Fusulinella timanica Rauser 1951, scale bar $=33 \mathrm{~mm}$, axial sections, bed $79.0 \mathrm{~m},(\mathrm{PMO}-43858 / 8 \mathrm{a})$. 14-17. Transitional specimens from Fusulinella to Protriticites, scale bar $=33 \mathrm{~mm}$, all axial sections, 14, bed 79.0 m, (PMO-43858/15a); 15, bed $79.0 \mathrm{~m}$, (PMO-43858/3a); $15 \mathrm{a}$, enlargement of figure $7-15$, scale bar $=110 \mathrm{~mm}$, primitive Protriticites wall structure with tectum, indistinct diaphanotheca and inner tectorium; small poor developed pores penetrate throughout the wall; 16, bed 76.0 m, (PMO-43858/14a); 16a, enlargement of figure $7-16$, scale bar $=110 \mathrm{~mm}$, primitive Protriticites wall structure with tectum, very thin but distinct diaphanotheca and inner tectorium with thin pores throughout the wall; 17, bed $79.0 \mathrm{~m}$, (PMO-43858/22a). 18. Protriticites ex gr. inflatus Bensh 1972, scale bar $=33 \mathrm{~mm}$, axial section, bed $79.0 \mathrm{~m}$, (PMO-43858/2a). 


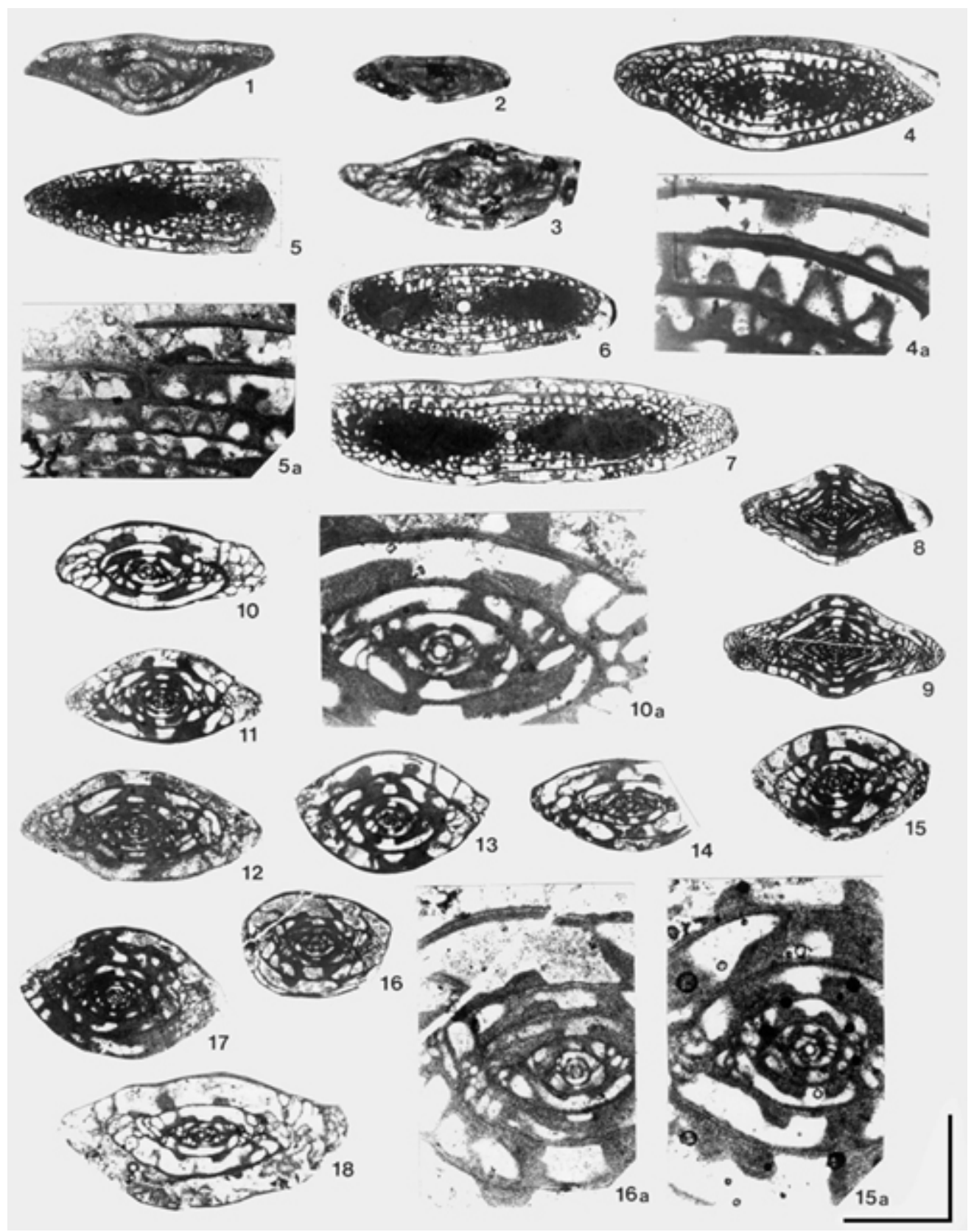


Figure 7.1-21. Fusulinid assemblage of Protriticites pseudomontiparus, Obsoletes obsoletus Zone. 1. Fusiella lancetiformis Putrya 1939, scale bar $=88 \mathrm{~mm}$, axial section, bed $87.5 \mathrm{~m}$, (PMO-43856/16a). 2. Fusiella rawi Lee 1927, scale bar $=88 \mathrm{~mm}$, axial section, bed $87.5 \mathrm{~m}$, (PMO-43856/23a). 3-6. Quasifusulinoides fusiformis (Rosovskaya 1952), scale bar $=33 \mathrm{~mm}$, all axial sections, 3, bed $87.5 \mathrm{~m},(\mathrm{PMO}-$ 43856/15a); 3a, enlargement of figure 8-3, scale bar $=110 \mathrm{~mm}$, Quasifusulinoides wall structure with tectum, indistinct diaphanotheca and dark inner tectorium with well developed coarse pores; 4, bed $81.0 \mathrm{~m}$, (PMO-43861/4a); 5, bed $81.0 \mathrm{~m}$, (PMO43861/14a); 6, bed $81.0 \mathrm{~m}$, (PMO-43861/15a). ). 7. Quasifusulinoides fortissimus (Rauser,1951), scale bar $=22 \mathrm{~mm}$, axial section, bed $81.0 \mathrm{~m}$, (PMO-43861/30a). 8 . Quasifusulinoides sp., $x 50$, inner volutions, wall structure with tectum, primatheca and dark inner tectorium with well developed coarse pores, bed $81.0 \mathrm{~m}$, (PMO-43861/5a). 910. Pseudofusulinella? pulchra (Rauser and Belyaev in Rauser-Chernousova, Belyaev, and Reitlinger 1937), scale bar $=22 \mathrm{~mm}$, both axial sections; 9 . bed $81.0 \mathrm{~m}$, (PMO-43861/24a); 10. bed $87.5 \mathrm{~m}$, (PMO-43856/9a). 11. Fusulinella bocki Moeller 1878, scale bar $=33 \mathrm{~mm}$, axial section, bed $81.0 \mathrm{~m}$, (PMO-43861/1a). 12. Fusulinella pseudobocki Lee and Chen 1934, scale bar $=33 \mathrm{~mm}$, axial section, bed $81.0 \mathrm{~m}$, (PMO43861/32a). 13. Protriticites pseudomontiparus Putrja 1948, scale bar $=33 \mathrm{~mm}$, axial section, bed $81.0 \mathrm{~m}$, (PMO-43861/16a). 14. Protriticites ovatus Putrja 1948, scale bar $=33 \mathrm{~mm}$, axial section, bed $81.0 \mathrm{~m}$, (PMO-43861/24a). 15. Protriticites variabilis Bensh 1972, scale bar $=33 \mathrm{~mm}$, axial section, bed $81.0 \mathrm{~m}$, (PMO-43861/8a). 16-17. Protriticites sphaericus Volozhanina 1962, scale bar $=33 \mathrm{~mm}$, both axial sections, bed $81.0 \mathrm{~m}, 16$, (PMO-43861/5a); 17, (PMO-43861/26a). ). 18. and 20. Praeobsoletes burkemensis (Volozhanina 1962), scale bar $=33 \mathrm{~mm}$, both axial sections, bed $81.0 \mathrm{~m}$, 18, (PMO-43861/3a); 20. (PMO-43861/12a); 20a, enlargement of figure 8-20, scale bar $=110 \mathrm{~mm}$, Praeobsoletes_wall structure with Fusulinella type wall in inner volutions (dark tectum, light diaphanotheca, inner and outer tectoriums) and with tectum and very thin gray primatheca with poor developed pores in outer volution. 19. Protriticites plicatissimus Kireeva 1950, scale bar $=33 \mathrm{~mm}$, axial section, bed $81.0 \mathrm{~m}$, (PMO43861/25a). 21. Protriticites plicatus Kireeva 1950, scale bar $=33 \mathrm{~mm}$, axial section, bed $81.0 \mathrm{~m}$, (PMO-43861/34a); 21a, enlargement of figure $8-21$, scale bar $=110 \mathrm{~mm}$, Protriticites wall structure composed in outer volution dark tectum, indistinct gray diaphanotheca, which became disappear, thin outer tectorium and relatively thick outer tectorium with well developed pores. 


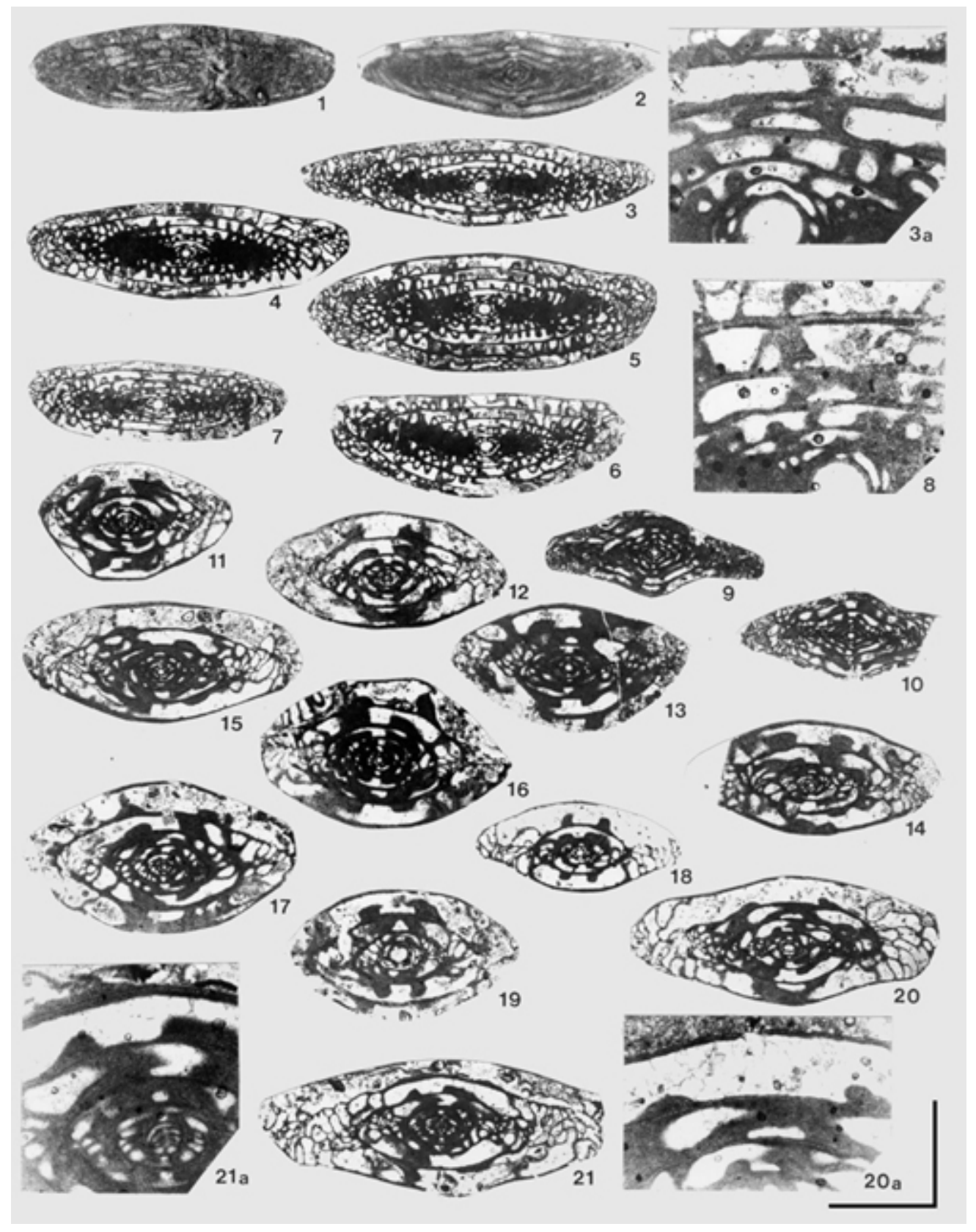


Figure 8.1-13. Fusulinid assemblage of Protriticites pseudomontiparus, Obsoletes obsoletus Zone. 1. Pseudofusulinella usvae (Dutkevich 1934b), scale bar $=22 \mathrm{~mm}$, axial section, bed $91.5 \mathrm{~m}$, (PMO-43862/2a). 2. Praeobsoletes burkemensis (Volozhanina 1962), scale bar $=33 \mathrm{~mm}$, axial section, bed $91.5 \mathrm{~m},(\mathrm{PMO}-43862 / 18 \mathrm{a})$; 2a, enlargement of figure 9-2, scale bar $=110 \mathrm{~mm}$, Praeobsoletes wall structure with Fusulinella type wall in first and second volutions (dark tectum, light diaphanotheca, inner and outer tectoriums) and with tectum and thin primatheca with developed pores in outer two volutions. 3. Obsoletes fusiformis Bensh 1972, scale bar $=33 \mathrm{~mm}$, axial section, bed $91.5 \mathrm{~m}$, (PMO-43862/14a); 3a, enlargement of figure 9-3, scale bar = $110 \mathrm{~mm}$, thin wall containing dark tectum and gray relatively thin layer with well developed coarse pores. 4. Protriticites ovatus Putrja 1948, scale bar $=33 \mathrm{~mm}$, axial section, bed $91.5 \mathrm{~m}$, (PMO-43862/12a). 5-7. Protriticites globulus Putrja 1948, scale bar $=33 \mathrm{~mm}$, all axial sections, bed $91.5 \mathrm{~m}, 5$, (PMO-43862/7a); 6, (PMO-43862/6a); 7, (PMO-43862/10a); 7a, enlargement of figure 9-7, scale bar $=110 \mathrm{~mm}$, thick wall of advanced Protriticites_containing dark tectum, gray diaphanotheca, inner and outer tectoriums; diaphanotheca and inner tectorium become joint with each other. Well developed coarse pores pierced the wall. 8. Protriticites sphaericus Volozhanina 1962, scale bar $=33 \mathrm{~mm}$, axial section, bed $91.5 \mathrm{~m}$, (PMO-43862/16a). 9. Protriticites ovoides Putrja 1948, scale bar $=33 \mathrm{~mm}$, axial section, bed $91.5 \mathrm{~m},(\mathrm{PMO}-43862 / 3 \mathrm{a})$; 9a, enlargement of figure 9-9, scale bar $=110 \mathrm{~mm}$, thick wall of advanced Protriticites, which has similar structure with 9-7a specimen, but pores became branched i.e. develop to the Schwagerinidae type wall structure. 10. Protriticites

subschwagerinoides Rosovskaya 1950, scale bar $=33 \mathrm{~mm}$, axial section, bed $91.5 \mathrm{~m}$, (PMO-43862/1a). 11. Protriticites pseudomontiparus Putrja 1948, scale bar $=33 \mathrm{~mm}$, oblique axial section, bed $91.5 \mathrm{~m},(\mathrm{PMO}-43862 / 9 \mathrm{a})$. 12. Protriticites globulus turkestanensis Bensh 1972, scale bar $=33 \mathrm{~mm}$, axial section, bed $91.5 \mathrm{~m}$, (PMO43862/5a); 12a, enlargement of figure $9-12$, scale bar $=110 \mathrm{~mm}$, thick wall of advanced Protriticites_similar with wall structure of $9-7$ a specimen. 13. Specimen transitional from Protriticites to Montiparus, scale bar $=33 \mathrm{~mm}$, axial section, bed $91.5 \mathrm{~m}$, (PMO43862/11a). 


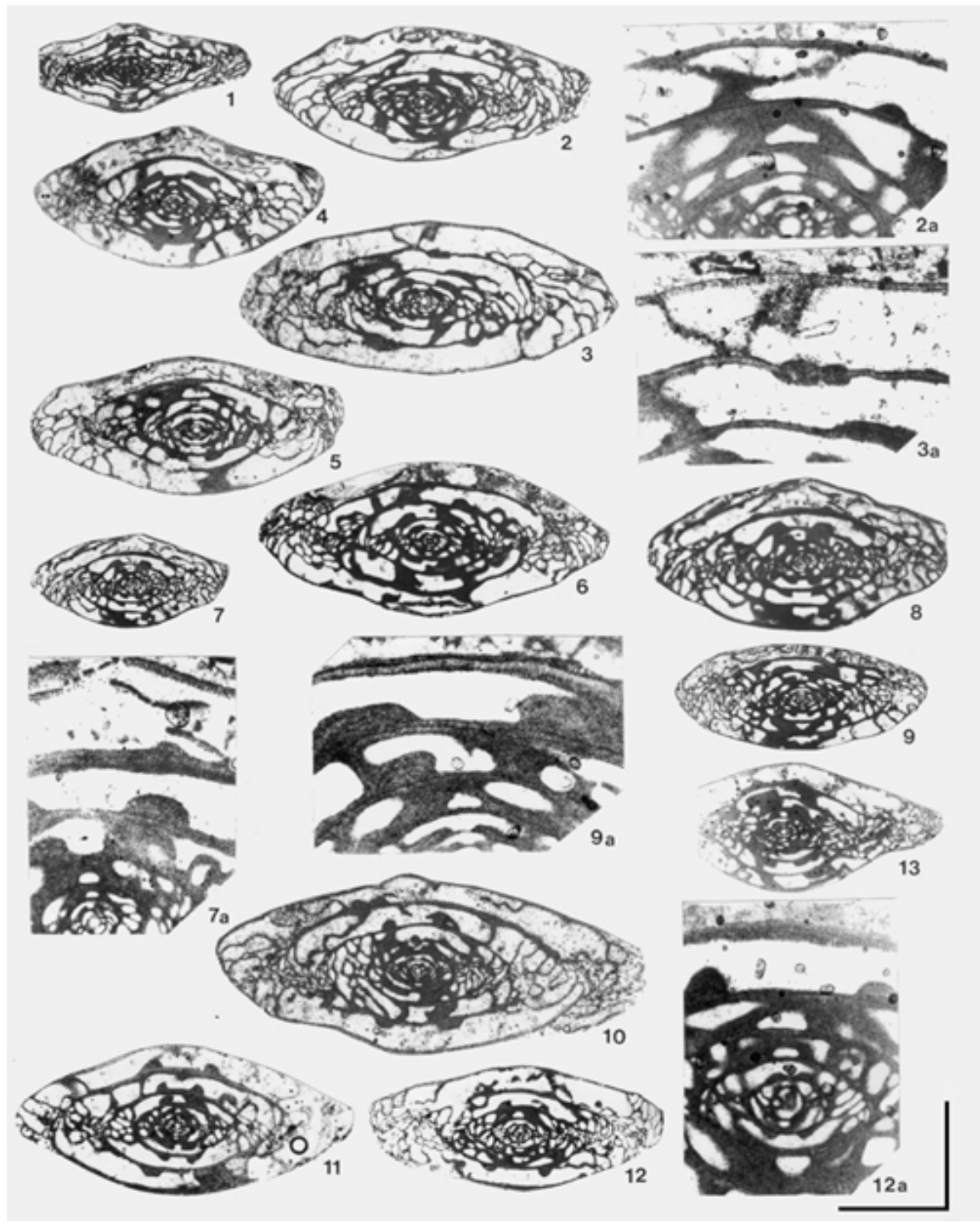


Figure 9.1-14. Fusulinid assemblage of Montiparus montiparus Zone. 1. Protriticites ovoides Putrja 1948, scale bar $=22 \mathrm{~mm}$, axial section, bed $95.5 \mathrm{~m},(\mathrm{PMO}-43854 / \mathrm{Ca}) .2$. Elongate specimen transitional from Protriticites to Montiparus, which probably formed lineage of elongate Montiparus, scale bar $=22 \mathrm{~mm}$, axial section, bed $95.5 \mathrm{~m}$, (PMO-43854/21a). 3. Subspherical specimen transitional from Protriticites to Montiparus, which probably formed lineage of subspherical Montiparus, scale bar = 22mm, axial section, bed $95.5 \mathrm{~m}$, (PMO-43854/26a). 4-6. Montiparus montiparus (Ehrenberg em. Moeller 1878), scale bar $=22 \mathrm{~mm}$, all axial sections, bed $95.5 \mathrm{~m}, 4$, (PMO-43854/23a); 5, (PMO-43854/31a). 6, (PMO-43854/24a). 7-11. Montiparus likharevi (Putrja 1939), scale bar $=22 \mathrm{~mm}$, all axial sections, bed $95.5 \mathrm{~m}, 7,(\mathrm{PMO}-$ 43854/27a); 7a, enlargement of figure 10-7, thick wall typical for the Schwagerinidae contains dark tectum, keriotheca and fragmentally developed outer tectorium; 8, (PMO43854/22a); 9, (PMO-43854/19a); 10, (PMO-43854/32a); 11, (PMO-43854/34a). 12. Montiparus umbonoplicatus (Rauser and Belyaev in Rauser-Chernousova, Belyaev, and Reitlinger 1936), scale bar = 22mm, axial section, bed $95.5 \mathrm{~m}$, (PMO-43854/24a). 13-14. Montiparus mesopachus Rosovskaya 1950 , scale bar $=22 \mathrm{~mm}$, both axial sections, bed $95.5 \mathrm{~m}, 13$. (PMO-43854/30a); 14. (PMO-43854/13a); 14a, enlargement of figure $10-14$, keriothecal wall present in all volutions; the wall is slightly recristallized. 


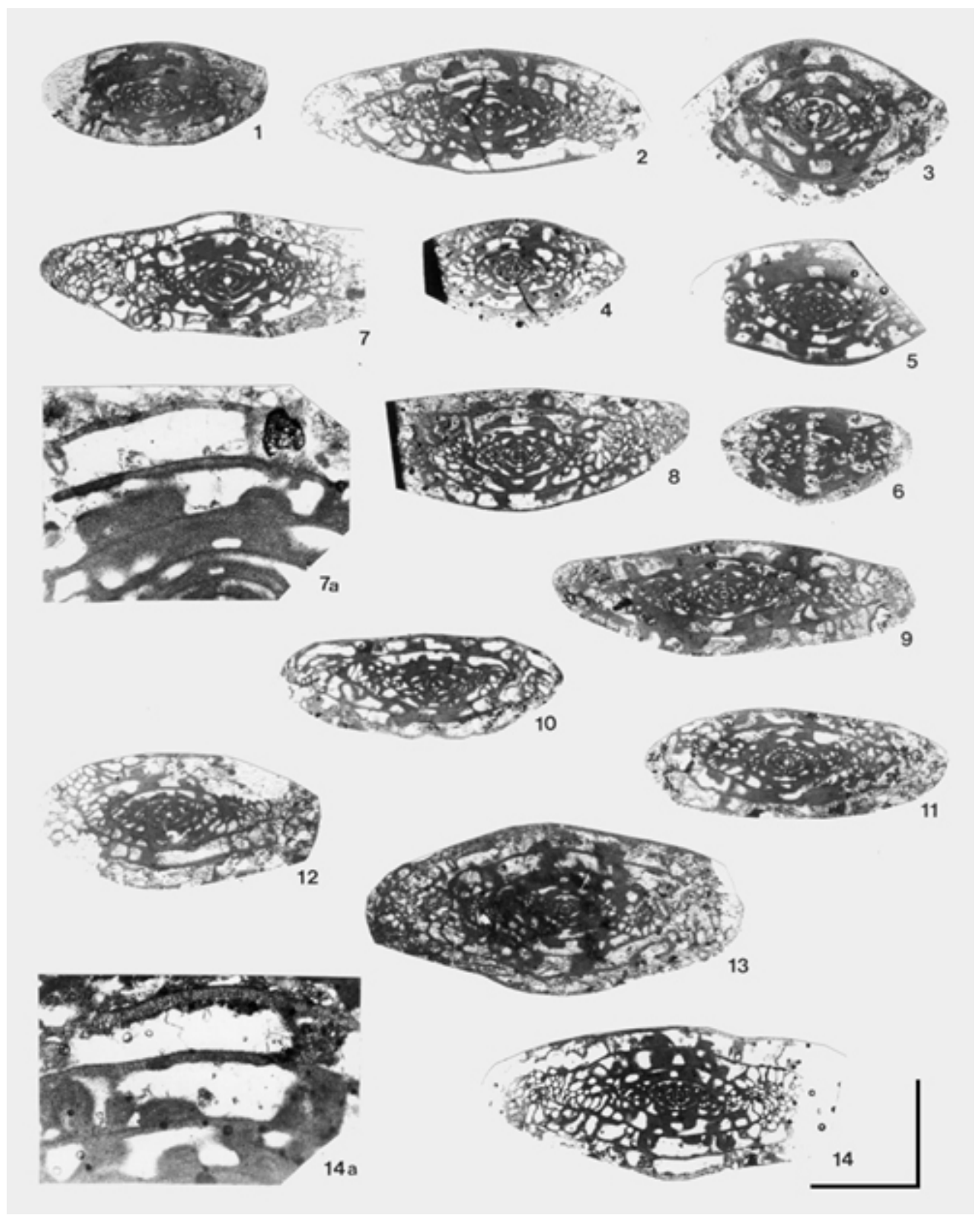


Figure 10. Correlation of fusulinid zones. Click on section of interest for zoom.

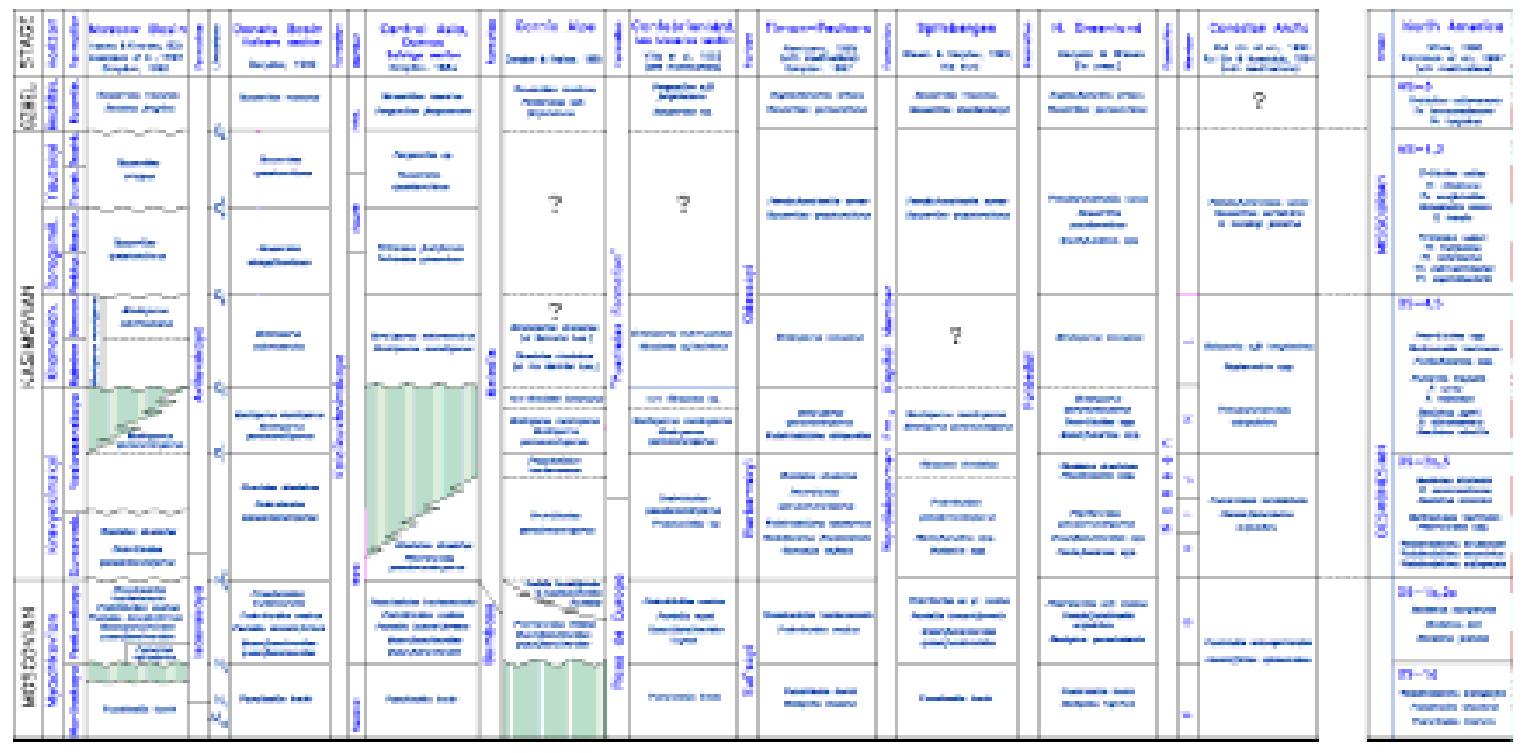


Figure 11. Comparative characteristic of the evolution trends of the Middle/Late Carboniferous of Russian-arctic and American fusulinids. Russian-arctic fusulinids.

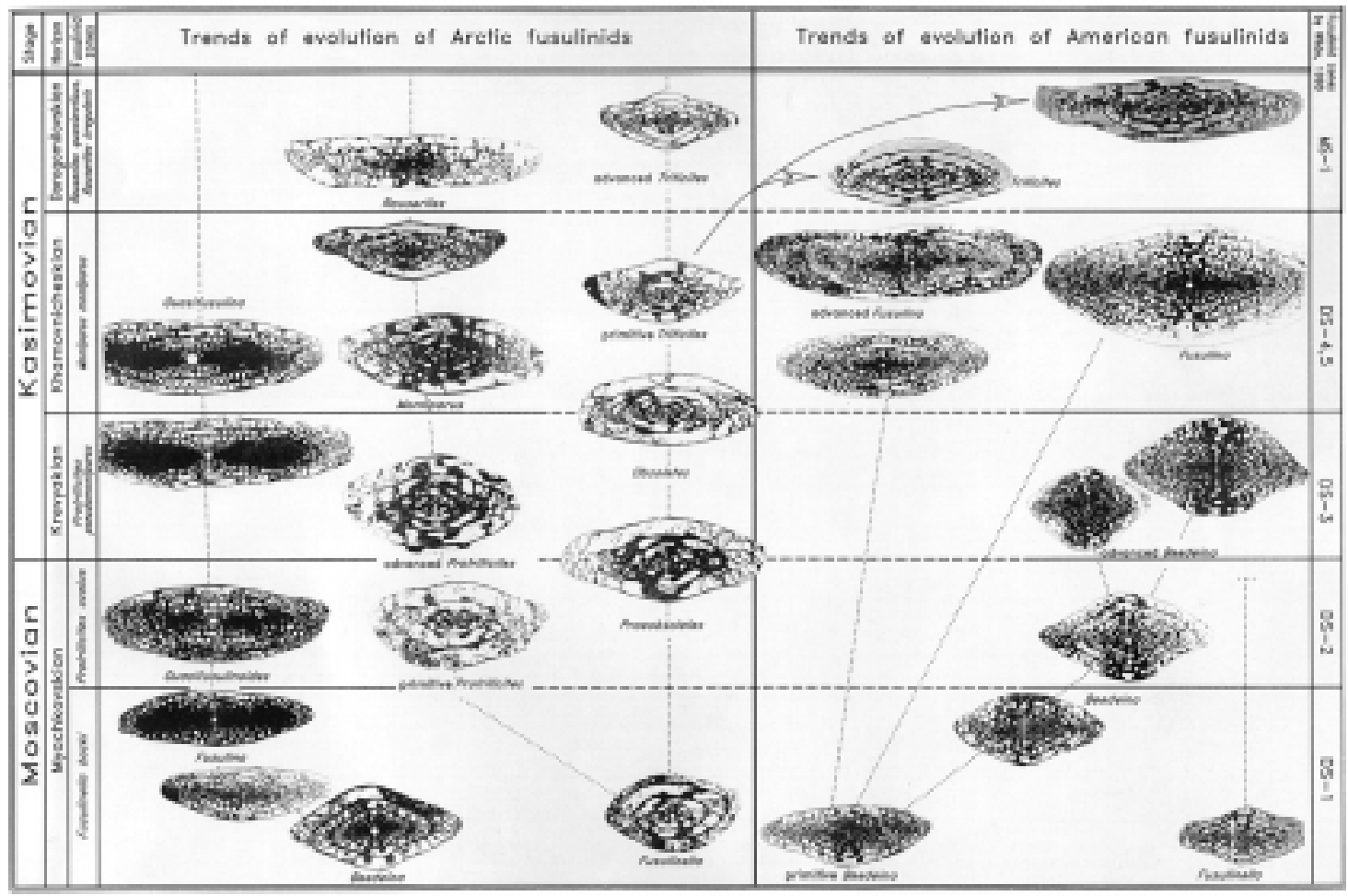

